\title{
Improvement of Trout Streams in Wisconsin by Augmenting Low Flows With Ground Water
}

\section{GEOLOGICAL SURVEY WATER-SUPPLY PAPER 2017}

Prepared in cooperation with Wisconsin Department of Natural Resources

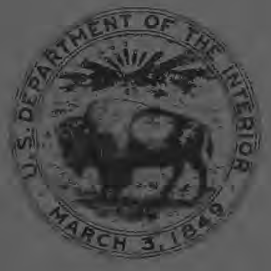




\title{
Improvement of Trout Streams
}

\section{in Wisconsin by Augmenting}

\section{Low Flows With Ground Water}

\author{
By R. P. NOVITZKI
}

3EOLOGICAL SURVEY WATER-SUPPLY PAPER 2017

Prepared in cooperation with Wisconsin

Department of Natural Resources

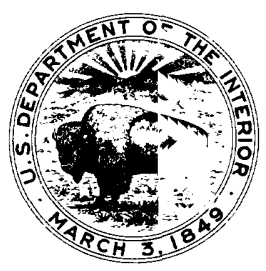

TINITED STATES GOVERNMENT PRINTING OFFICE, WASHINGTON : 1973 
UNITED STATES DEPARTMENT OF THE INTERIOR

ROGERS C. B. MORTON, Secretary

GEOLOGICAL SURVEY

V. E. McKelvey, Director

Library of Congress catalog-card No. 72-600348

For sale by the Superintendent of Documents, U.S. Government Printing Office Washington, D.C. 20402 - Price 55 cents domestic postpaid or 35 cents GPO Bookstore Stock Number 2401-00305 


\section{CONTENTS}

$\longrightarrow$

Abstract
Introduction
Purpose and scope
Location of areas
Previous studies
Acknowledgments and cooperation
Bittle Plover River
$\quad$ Reasons for choice
Geology and hydrology of area
Experiment
Technique
$\quad$ Procedure

Findings _............ 10

Hydrologic response _._.

Temperature _._. 14

Dissolved oxygen _....... 19

Criteria for site selection _-_._. 20

Selection of stream

Selection of augmentation site

Black Earth Creek _... 23

Setting -

History of trout habitat

Geology and hydrology of area _.............. 24

Concurrence with site-selection criteria - 24

Application -

Improvements sought _........ 26

Physical setup of monitoring -

Procedure -_- 27

Evaluation -_._- 29

Discharge _.

Temperature -_.

Dissolved oxygen _-_._. 33

Recommendations -

Applications _- Aditional studies 38

Additional studies _. 39

Conclusions _...

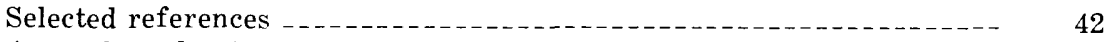

Appendix - development of a model for predicting maximum or minimum stream temperatures 


\section{ILLUSTRATIONS}

FIgURE 1. Map showing location of study areas

2. Map showing study reach on the Little Plover River, Portage County, Wis., data-monitoring sites, water-table contours for October 1962, and source of augmentation flow

3. Graph showing measured ground-water runoff to the Little Plover River below monitor site 7, and inferred ground-water runoff based on analysis of stream temperature, December 12, 1968

4. Temperature profile in the Little Plover River, December 12, 1968

5. Graph showing fluctuations in DO, water temperature, and water levels at monitor site 2 on the Little Plover River during augmentation _......................................

6. Graph showing discharge of the Little Plover River at monitor site 2 during augmentation

7. Graph showing time of travel and lag between initial rise and peak flow in the Little Plover River, determined from rising stream stages as a result of augmertation.

8. Observed profile of maximum water temperature in the Little Plover River during augmentation, September 14, 1968, compared to the natural profile and to the extreme case of no ground-water runoff in the study reach

9. Profiles of hypothetical maximum water temperatures in the Little Plover River during extreme summer conditions, based on a stream-temperature model

10. Profile of hypothetical minimum water temperatures in the Little Plover River during extreme winter conditions, based on a stream-temperature model

11. Graph showing diurnal cycles of DO at monitor site 2 on the Little Plover River before and during augmentation

12. Map showing study reach on Black Earth Creek, Dane County, Wis., data-monitoring sites, and source of augmentation flow

13. Graph showing measured ground-water runoff and tributary inflow to Black Earth Creek, and inferred groundwater runoff based on analysis of stream temperature, May 1970

14. Temperature profile in Black Earth Creek, May 1970, and the inferred ground-water runoff

15. Graph showing time of travel and lag between leading edge and peak of dye concentration in Black Earth Creek

16. Profile of minimum water temperatures in Blacl- Earth Creek during intermittent augmentation (Sept. 23) compared to temperatures during natural flow (Sept. 26) 
Page

Figure 17. Profiles of hypothetical minimum water temperatures in Black Earth Creek during natural flow and in response to augmentation at one or several sites, based on a stream-temperature model

18. Profiles of hypothetical maximum water temperatures in Black Earth Creek during natural flow and in response to augmentation at one or several sites, based on a stream-temperature model _.........................

19. Selected DO profiles in Black Earth Creek before improvement in sewage treatment facilities (1968) and

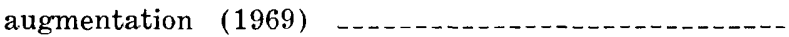

20. Graph showing diurnal cycle of dissolved oxygen observed in Black Earth Creek at monitor site 5 during augmentation in 1969 compared to observations obtained by the Wisconsin Department of Natural Resources in 1967 and 1968

21. Profiles of minimum DO levels in Black Earth Creek during intermittent augmentation and during natural flow

22. Graphs showing diurnal DO cycle and stream-stage fluctuations in Black Earth Creek at monitor site 5, September 23-24, 1969, in response to intermittent augmentation

23. Graph showing diurnal DO cycle in Black Earth Creek at monitor site 5, July 26-27, 1969, during continuous augmentation

24. Theoretical water-temperature profile resulting if temperature at $L=0$ is held constant

25. Typical profile of maximum water temperatures, showing the effect of ground-water runoff compared to the theoretical profile

26. Profile of maximum water temperatures obtained by superimposing the effect of ground-water runoff on the theoretical profile

\section{TABLES}

TABLE 1. Chemical analyses of water from Black Earth Creek, from manmade ponds below the sewage-treatment plant, and from the gravel pit pond used for augmentation ......-

2. Computations to define profile of maximum water temperatures in the Little Plover River for September 14, 1968

3. Comparison of computed and observed stream temperatures in the Little Plover River 


\title{
IMPROVEMENT OF TROUT STREAMS IN WISCONSIN BY AUGMENTING LOW FLOWS WITH GROUND WATER
}

\author{
By R. P. Novitzki
}

\begin{abstract}
Approximately 2 cubic feet per second of ground water were introduced into the Little Plover River in 1968 when natural streamflow ranged from 3 to 4 cubic feet per second. These augmentation flows were retained undiminished through the 2-mile reach of stream monitored. Maximum stream temperatures were reduced as much as $5^{\circ} \mathrm{F}\left(3^{\circ} \mathrm{C}\right)$ at the augmentation site during the test period, although changes became insignificant more than 1 mile downstream. Maximum temperatures might be reduced as mucl as $10^{\circ} \mathrm{F}\left(6^{\circ} \mathrm{C}\right)$ during critical periods, based on estimates using a streamtemperature model developed as part of the study. During critical periods significant temperature improvement may extend 2 miles or more downstream. Changes in minimum DO (dissolved oxygen) levels were slight, primarily because of the high natural Do levels occurring during the test period. Criteria for considering other streams for flow augmentation are developed on the basis of the observed hydrologic responses in the Little Plover River.
\end{abstract}

Augmentation flows of nearly $2 \frac{1}{2}$ cubic feet per second of ground water were introduced into the headwater reach of Black Earth Creek from the end of June through mid-October 1969. Streamflow ranged from 1 to 2 cubic feet per second at the augmentation site, and the average flow at the gaging station at Black Earth, approximately 8 miles downstream, ranged from 25 to 50 cubic feet per second. Augmentation flows were retsined through the 8-mile reach of stream. Temperature of the augmentation flow as it entered the stream ranged from $60^{\circ}$ to $70^{\circ} \mathrm{F}$ (about $16^{\circ}$ to $21^{\circ} \mathrm{C}$ ) during the test period, and minimum stream temperatures were raised $5^{\circ} \mathrm{F}\left(3^{\circ} \mathrm{C}\right)$ or more at the augmentation site, with changes extending from 2 to 3 miles downstream. Augmentation during critical periods could maintain stream temperatures between $40^{\circ}$ and $70^{\circ} \mathrm{F} \quad\left(4^{\circ}\right.$ and $\left.21^{\circ} \mathrm{C}\right)$ through most of the study reach. DO levels were increased by as much as 2 milligrams per liter or more below the augmentation site, although the improvement diminished to approximately 1 milligram per liter downstream in the problem reach. During critical periods DO improvement in the problem reach would be somewhat greater.

Flow augmentation would not be necessary during normal conditiors in either of the streams studied. Critical DO and temperature levels are not known to occur in the Little Plover River. Since the construction of secondary treatment facilities at the Cross Plains sewage-treatment plant, critical 
DO levels are no longer expected to be a problem in Black Earth Creek. However, results from this study may be used to estimate the effectiveness of flow augmentation in other streams in similar areas in which critical DO or temperature levels may occur.

\section{INTRODUCTION}

The gradual loss or deterioration of trout waters in Wisconsin is cause for concern among conservationists. A recent publication by the Wisconsin Conservation Department (1966) lists more than 1,500 trout streams within the State, but the total mileage of trout waters decreases each year as more reaches of streams become unfit habitat for trout. Trout are the most sensitive of the game fishes and, consequently, are the first to respond to habitat deterioration. Increases or decreases in stream temperature, decreases in DO (dissolved oygen), and decreases in living space can eliminate trout from a reach of a stream.

\section{PURPOSE AND SCOPE}

The purpose of this study was to evaluate the possibility of improving trout streams by augmenting low flows with pumped ground water. The study sought to determine the hydrologic responses, changes in stream temperature, changes in DO, and possible changes in other stream parameters that influence trout habitat.

Approximately $2 \mathrm{cfs}$ (cubic feet per second) of augmenting flow was introduced into the Little Plover River and Black Earth Creek, and the responses of various stream parameters to the increased flow were observed. Streamflow was monitored to determine whether increases achieved by augmentation were retained for significant distances downstream from the discharg point. Aspects of the hydraulic system influencing that retention were defined. DO levels in the stream were monitored to determine changes occurring in response to augmentation. Stream-temperature changes at the point of discharge and at several points downstream were determined, and a stream-temperature model was developed to evaluate the effectiveness of augmentation under hypothetical critical conditions.

The Little Plover River was chosen to define the hydrologic aspects of augmentation because background information was available from previous studies. Several years of streamflow, water-level, and temperature data were available, and the interaction of the ground-water system and the surface streams was adequately known. The Little Plover River, however, had no habitat problems amenable to.improvement by augmentation.

Thus, a two-phase approach was used. The study of the Little 
Plover River established the hydrologic feasibility of augmentation and provided criteria for choosing the stream for the second phase of the study. The second stream, Black Earth Creek, was chosen to determine the response of critical stream reaches to flow augmentation from pumped ground water.

\section{LOCATION OF AREAS}

The Little Plover River is a trout stream in Portage County, in the center of the State (fig. 1). It enters the Wisconsin River near

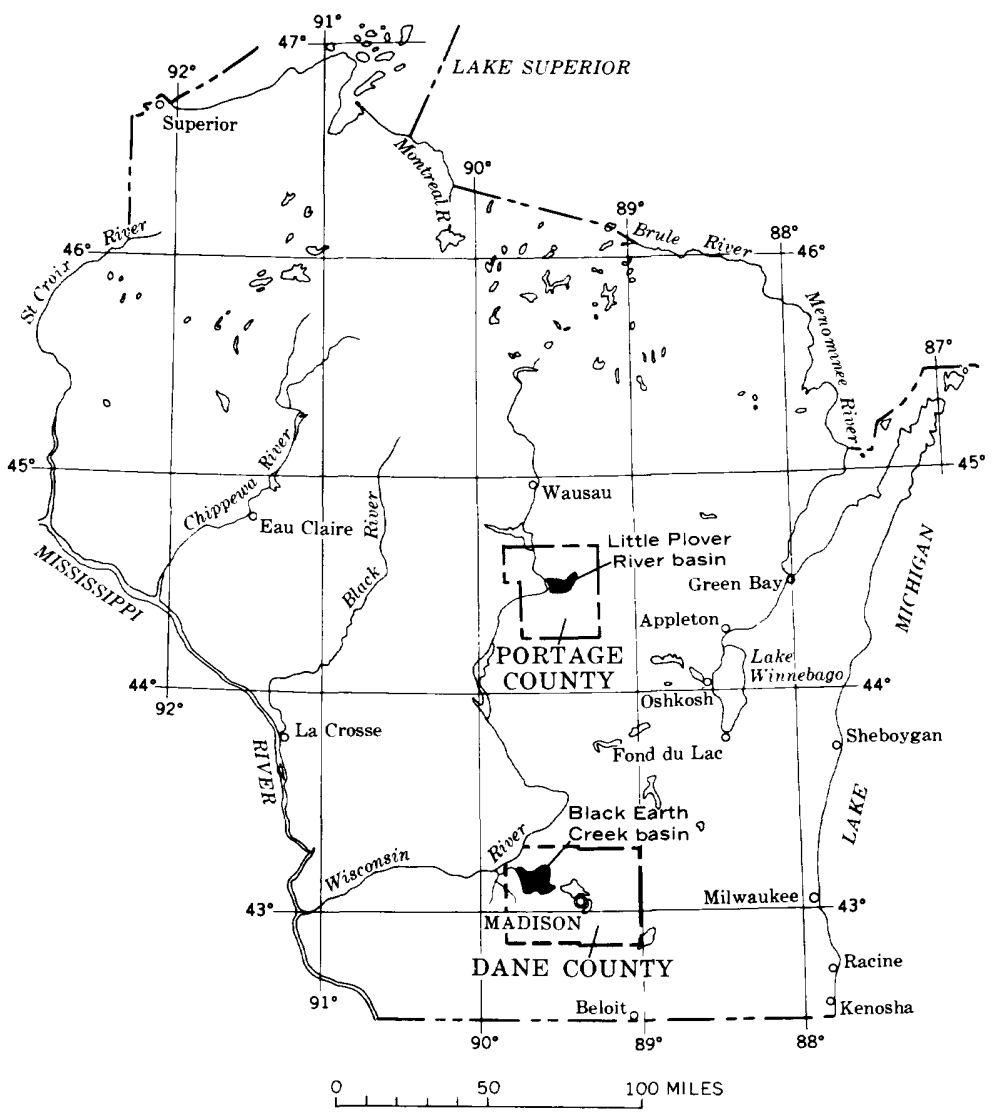

Figure 1.-Location of study areas.

the north edge of the town of Plover, approximately 3 miles south of Stevens Point.

Black Earth Creek is located in Dane County, and is a popular trout stream in the southern part of the State (fig. 1). Its headwater area is approximately 2 miles from the city limits of Madi- 
son. Black Earth Creek is a tributary of Blue Mounds Creek, which enters the Wisconsin River near Arena.

\section{PREVIOUS STUDIES}

Studies in the central sand-plain area that include the Little Plover River basin have been conducted by Holt (1965), Weeks, Ericson, and Holt (1965), and Weeks and Stangland (1971). These studies define the geology and hydrology of the area. The study by Weeks and Stangland specifically determined the effects of irrigation development on the ground-water system and on streamflow. Studies in Dane County that include the Black Earth Creek basin have been conducted by Cline $(1963,1965)$, Collier (1963), and Dury (1964). These studies define the geology and hydrology of the area and include specific aspects of surface water, such as streamflow and sedimentation characteristics.

Numerous studies have established the feasibility of streamflow augmentation from reservoir storage. Some studies have also considered the effects of reservoir discharge downstream (Churchill, 1965). Although the feasibility of augmentation from ground water has been suggested, no study has specifically considered improvements to the stream resulting from augmentation with ground water.

Several investigators have presented optimum temperature values for various species of fish (Brasch and others, 1962; Brynildson and others, 1964; and McKee and Wolf, 1963). The optimum temperature range for brown trout is about $60^{\circ}-65^{\circ} \mathrm{F}$ $\left(16^{\circ}-18^{\circ} \mathrm{C}\right)$, and for rainbow and brook trout is about $55^{\circ}-60^{\circ} \mathrm{F}$ $\left(13^{\circ}-16^{\circ} \mathrm{C}\right)$. Upper tolerance levels reported for trout usually are between $65^{\circ}$ and $75^{\circ} \mathrm{F}\left(18^{\circ}\right.$ and $\left.24^{\circ} \mathrm{C}\right)$, and the lower tolerance levels usually are between $40^{\circ}$ and $45^{\circ} \mathrm{F}\left(24^{\circ}\right.$ and $\left.29^{\circ} \mathrm{C}\right)$.

The lower limit of DO has been reported (Burdick and others, 1954; Whitmore and others, 1960; Wiebe and McGavok, 1932; Fry, 1959 ; Jones, 1952; and Shepard, 1955). Lethal DO levels usually are reported in the range of $1-3 \mathrm{mg} / 1$ (milligrams per l:ter). However, the normal activity of fish may be affected at DO levels as low as $5-7 \mathrm{mg} / \mathrm{l}$. Thus, it appears that optimum DO levels would be above concentrations of $7 \mathrm{mg} / \mathrm{l}$.

\section{ACKNOWLEDGMENTS AND COOPERATION}

This study was conducted by the U.S. Geological Survey in cooperation with the Wisconsin Department of Natural Resources. Special acknowledgment is made to the Okray Produce Company, which provided a well and equipment for study of the Iittle Plover River, and to the Capitol Sand and Gravel Company, which provided water and equipment for the study of Black Earth Creek. 
Appreciation also is extended to $\mathrm{Mr}$. Jerome Hillebrand, who granted permission to test his ponds as an alternate source of augmentation water for Black Earth Creek. Property owners in both areas are thanked for access permitted at various times during the study. Personnel of the Wisconsin Department of Netural Resources provided background information for Black Earth Creek.

\section{LITTLE PLOVER RIVER}

\section{BACKGROUND}

REASONS FOR CHOICE

The Little Plover River is a Class I trout stream according to the Wisconsin Department of Natural Resources' classification system (Wisconsin Conservation Department, 1966, p. 60). Class I streams are good trout waters with habitat suitable for natural reproduction. Thus, results from this study apply to similar trout streams throughout the State.

The comprehensive data from previous studies provided means to evaluate augmentation improvements. Continuous streamflow records were available at two gaging stations for the period 195968. These two stations are the Little Plover River near A rnott (5-4006) and Little Plover River at Plover (5-4006.5). StreamHow characteristics such as average flow, flow duration, low flows, and flood flows were determined by Weeks, Ericson, and Holt (1965). Water-temperature records were available at the "near Arnott" station for the period 1960-68 and the "at Plover" station for the summer months of 1960-62. Ground-water contributions to streamflow were established by seepage measurements made in 1961 and 1962.

The adequacy of the ground-water supply also was established in earlier studies. Irrigation wells in the Little Plover River basin commonly yield more than $1,000 \mathrm{gpm}$ (gallons per minute) (Holt, 1965, p. 33). Because transmissivity in the glacial outwash deposits ranges from 150,000 to 280,000 gpd (gallons per day) per foot (Weeks and others, 1965, p. 16), drawdown in wells is not excessive, and interference between wells is negligible.

GEOLOGY AND HYDROLOGY OF AREA

The glacial outwash deposits form the main aquifer in the Little Plover River basin (Weeks and others, 1965, p. 15). Morainal deposits and peat and channel deposits are less significant as aquifers but compose part of the ground-water reservoir. The unconsolidated deposits are underlain by less permeable sandstone, which overlies crystalline rock of Precambrian age. A buried sanc'stone ridge forces ground water upward and into the Little Plover River. 
Ground-water runoff (ground water discharged into the stream channel as spring or seepage water) comprises more than 80 percent of the flow in the Little Plover River, and, as a result, streamflow is very stable (Weeks and others, 1965, p. 27). At the upper end of the study reach the average flow is $3.2 \mathrm{cfs}$; it ranged from 0.8 to $66 \mathrm{cfs}$ during the period 1959-67. Ground-water movement toward the stream is shown in figure 2 .

\section{EXPERIMENT}

TECHNIQUE

Because increased stream volume is related to most of the improvements sought, streamflow was determined by measuring discharge at various stream stages to define a stage-discharge relationship, and, subsequently, by monitoring fluctuations of stream stage. Stream-stage recorders were operated at thres sites, and intermittent gage-height readings were obtained at five additional locations (fig. 2).

A series of discharge measurements was obtained to establish the streamflow profile and define ground-water runoff. The streamflow increases determined by discharge measurements at six points in the study reach compared well with those obtainec' previously (fig. 3).

However, a detailed stream-temperature profile obtained December 12, 1968, (fig. 4) indicated a slightly different pattern of ground-water runoff than that indicated by the discharre measurements. (Ground-water runoff at a constant temperature may either raise or lower the stream temperature if the two original temperatures differ (appendix). The stream-temperature profile can be analyzed to show reaches where ground water enters the stream.) The streamflow profile (fig. 3) was modified on the basis of the December 12 temperature data. Although this more detailed definition of ground-water runoff was not necessary to define changes in streamflow in response to augmentation, it was essential to analyze the response of stream temperature.

The response of the ground-water system to incres sed stream stage also was observed during augmentation. Two sand-point piezometers were installed at each of the monitoring sites shown in figure 2. The piezometers were located approximately 5 and 15 feet from the streambank and were driven to a depth of 10 feet. Ground-water levels were measured intermittently during the study.

Continuous water-temperature records were obtainec' at monitor sites 2, 4, 6, and 7 (fig. 2) to show the effects of augmentation. Recording thermometers, accurate to within $1^{\circ} \mathrm{F}\left(0.6^{\circ} \mathrm{C}\right)$, were 


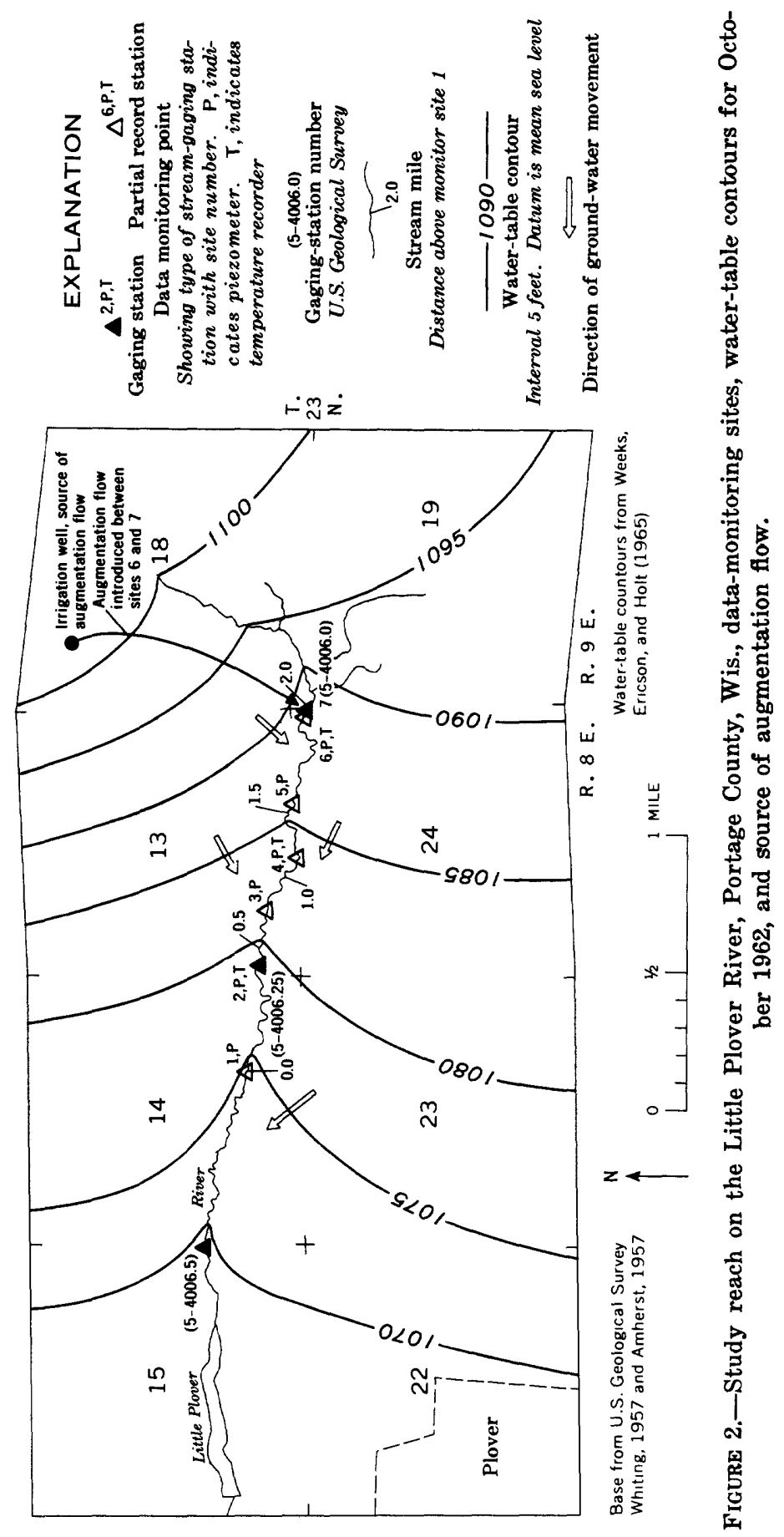




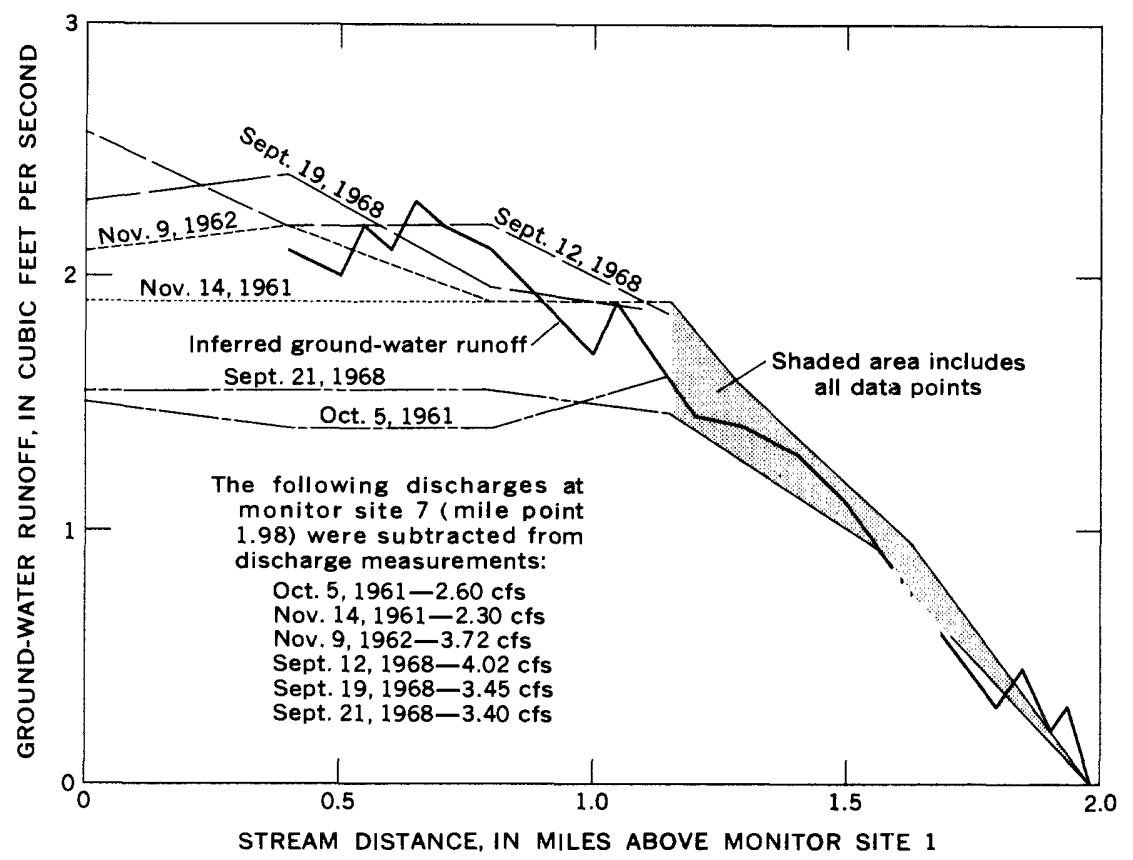

Figure 3,-Measured ground-water runoff to the Little Plover River below monitor site 7, and inferred ground-water runoff based on analysis of stream temperature, December 12, 1968.

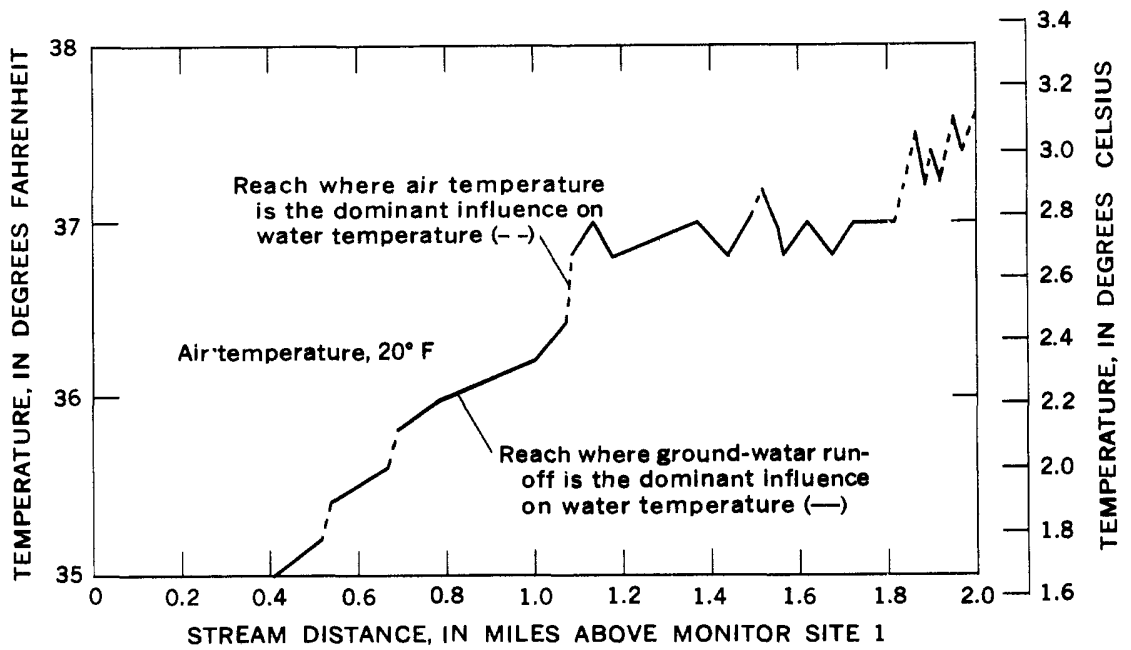

Figure 4.-Temperature profile in the Little Plover River, December 12, 1968.

used. Additional temperature observations were made intermittently at the remaining monitor sites during the test period. 
DO concentrations were monitored at several points within the study reach before and during the test period with a temperature compensated oxygen meter. The assumed accuracy of the meter under field conditions was $0.5 \mathrm{mg} / \mathrm{l}$.

Because the flow in trout streams is predominantly from ground water, significant changes in water quality were not expected. Chemical analyses indicated that the water from the augmentation well was essentially the same as the stream water (F. A. Kammerer, Jr., and E. L. Skinner, oral communs., 1969).

PROCEDURE

To avoid interaction between the well and the stream, augmentation flow was provided by a well located a considerable distance from the study reach (fig. 2). No streamflow depletion as a result of the pumping was observed in the study reach during the augmentation period.

Ground water was pumped in September 1968 when midday stream temperatures were as high as $70^{\circ} \mathrm{F}\left(21^{\circ} \mathrm{C}\right)$. (The well was not available earlier because it was used for irrigation.) Pumping was continuous for 96 hours, beginning at 4 p.r. on September 13 and ceasing at 4 p.m. on September 17.

Water from the well was transmitted overland through ir:igation pipe and discharged into the stream between monitor sites 6 and 7 (fig. 2). The well discharge was measured at the stream end of the pipe and remained relatively constant at $980 \mathrm{gpm}$ $(2.2 \mathrm{cfs})$ throughout the test period.

Water temperature and DO were measured at the well ard at the stream end of the pipe. Water temperature remainet at $50^{\circ} \mathrm{F}\left(10^{\circ} \mathrm{C}\right)$ at both points. DO was $8.5 \mathrm{mg} / 1$ at the well but increased to $10.0 \mathrm{mg} / \mathrm{l}$ at the stream. This increase apparently was the result of air introduced in the portable irrigation pipe. In view of the relatively high DO concentration (approximately 90 percent of saturation), no effort was made to aerate the discharge further.

Stream-stage, temperature, DO, and ground-water levels were observed at each monitor site during the test period. Observations were made at 15-minute intervals until a rise in stream stage and change in temperature indicated that the augmenting flow had reached the site. Observations were then made at 2 - to 5 -minute intervals until equilibrium was reached, at which time the interval between observations again was lengthened. Monitoring continued after pumping stopped until equilibrium was reached. Rain began shortly after the pump was shut off, and observations ended when response to the precipitation became obvious. 


\section{FINDINGS \\ HYDROLOGIC RESPONSE}

The effects of streamflow augmentation on the str?am-aquifer system include immediate response of ground-water levels and streamflow, as well as changes in the long-term water budget. The short-term response of ground-water levels near the stream and of various stream parameters were defined by direct observation. However, the long-term responses were inferred from general hydrologic principles applicable to this region.

Augmentation of streamflow from ground-water sources affects the stream-aquifer system. During augmentation the amount of ground water entering the stream increases, and ground-water levels decline. After augmentation ceases the amount of ground water entering the stream decr?ases while storage is being replenished. However, the long-term water budget for the basin remains balanced if the total amount of ground water entering the stream (including augmentation flow) does not exceed the natural ground-water runoff to the stream.

For practical purposes the amount of water available for augmentation may be somewhat different than the amount determined from water-budget considerations only. In some streamaquifer systems recharge may be poor, and replenishment of water withdrawn for augmentation may be incomplete, resulting in a net loss from ground-water storage. Conversely, decreased evapotranspiration from ground water as a result of lowered water levels may yield a net increase in ground-water runoff. Also, increased recharge may occur as a result of additional storage capacity available during recharge events.

The volume of augmenting flow that will be practical in most trout streams during critical periods will normally bo such that the water budget for the stream-aquifer system will remain balanced, and the net effect on the system will be a shift in timing of the runoff. Ground-water runoff will be more than normal during the critical period but will be less than normal during a later, noncritical period.

Several factors affect the magnitude of the shift in timing in the stream-aquifer system. High pumpage rates for extended periods cause the greatest depletion of ground-water storage and the most significant shifts in timing. Where induced recharge from surface sources to the pumping well decreases the amount of ground water obtained from ground-water storage, the resultant time necessary for storage replenishment also is reduced. Such basin characteristics as a low infiltration rate or low aquifer permeability extend the time required for storage replenishment. 
In this study the augmentation was too small and too short to cause a noticeable reduction of ground-water runoff following augmentation, and the shift in timing of ground-water rinoff was not apparent.

The typical short-term response of ground-water levels near the streams indicated little or no change in the amount of ground water moving toward the stream (fig. 5). Water-level changis in the aquifer were almost instantaneous, and gradients toward the stream diminished only slightly. The small decrease was offset by an increase in the area of the stream receiving groundwater runoff, so that the change in ground-water runoff was negligible. This analysis is confirmed by examination of the discharge-hydrograph for site 2 (fig. 6). The only exception was at site 3 , where the natural water-level gradients were relatively flat and the increased stream stage canceled the gradient toward the stream.

None of the added water was lost within the study reach because water-level gradients were toward the stream throuchout the test. Ground-water levels rose slightly near the stream (fig. 5) as a result of the damming effect of higher stream stages, but gradients toward the stream were retained. The natural disch arge at monitor site 2 (fig. 6) was obtained by correlation witr discharge at monitor site 7 above the augmentation site. This curve is approximately parallel to the observed hydrograph, indicating that the initial increase of $2.2 \mathrm{cfs}$ was maintained throughout the test period. Thus, retention of augmenting flow volumes prohably can be expected in streams where the initial slope of the water table is toward the stream.

Increases in streamflow and stream stage indicate increases in trout living space; however, the effective increase in living space is not directly proportional to changes in either stream volume or stream depth. Detailed studies of relations between stream volume and other factors that influence living space have been discussed by others (R. J. White, written commun., 1964, T'/hite and Brynildson, 1967). The observed changes in stream volume and stage are discussed as an indirect indication of incr?ased living space.

An increase in living space probably was associated with the increased streamflow. The change in streamflow, as a percentage of natural flow, was greater at the upper end of the study reach than farther downstream. At site 6 the augmenting flow represented an increase of 61-71 percent (natural st:eamflow was declining during the test period). However, at site 2, 


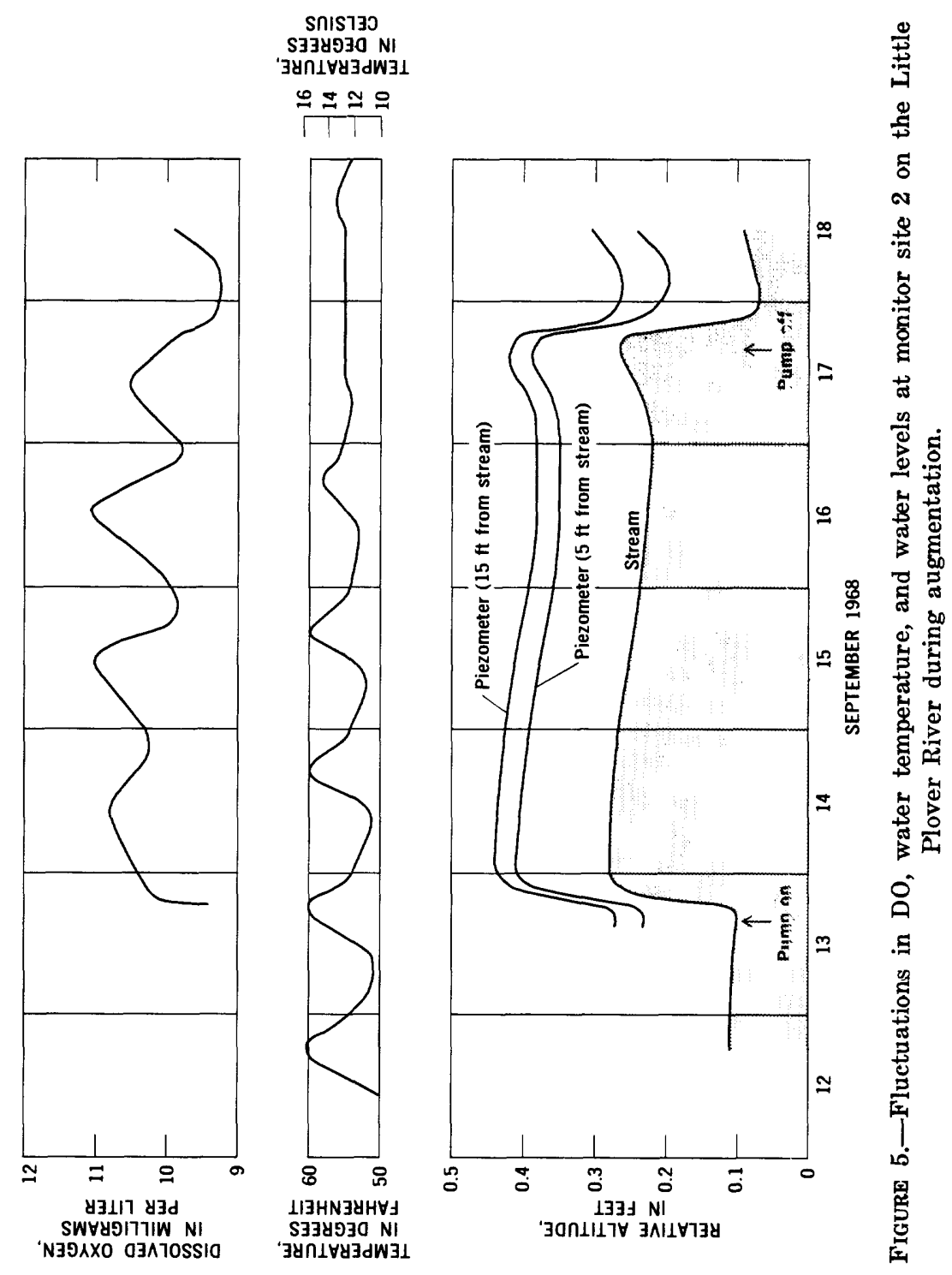




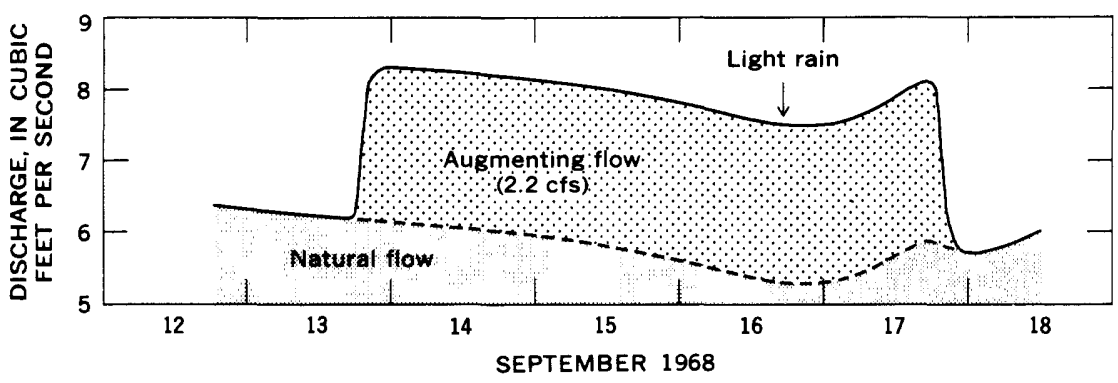

Figure 6.-Discharge of the Little Plover River at monitor site 2 during augmentation.

where natural flow is greater (fig. 3 ), the increase in streamflow was only 38-42 percent.

An estimate of the change in cross-sectional area of the stream also provides an indication of the change in living space associated with augmentation. The average cross-sectional area is determined by dividing the known flow volume by the mean velocity. At site 6 the velocity increased from $0.6 \mathrm{fps}$ (feet per second) to $0.7 \mathrm{fps}$ with the increase in flow. Computations based on these figures indicate an estimated increase in area of 2.4 square feet, approximately 45 percent, during the test period. At site 2 , where velocities increased more, the computed charge in area was only about 10 percent.

Stream depth also increased in response to augmentation. Stages increased 0.1 foot in the wide, shallow reaches of the stream, and as much as 0.2 foot in the narrow reaches. At site 1 , representative of the wider sections, stream depth increased approximately 15 percent. At site 6, representative of the narrower sections, stream depth increased approximately 25 percent. These figures represent changes occurring in the shallow sectic ns of the stream only, where pre-augmentation depths typically were in the range of 0.5-1.0 foot. In the deeper pools the percentege of change was much smaller, perhaps about 5 percent.

The time for flow to travel through the study reach was approximately $51 / 2$ hours (fig. 7). Although the initial rise in stag? preceeds the peak by as much as 2 hours, aspects of stream improvement are more closely associated with the peak flow, and that must be used in determining when improvement will be noted at a particular point.

Although time of travel is not particularly important with respect to a continuous pumping scheme, it is crucial if intermittent pumping is considered. For example, to decrease maxi- 


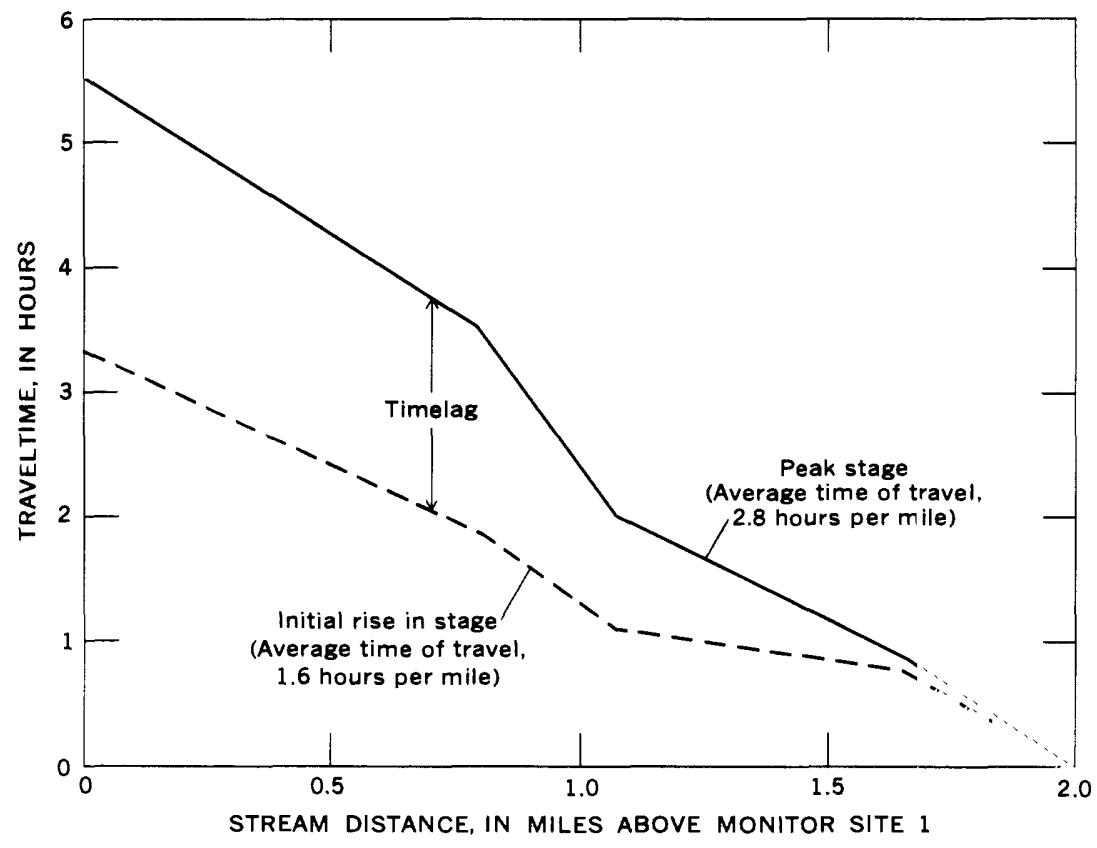

Figure 7.-Time of travel and lag between initial rise and peak flow in the Little Plover River, determined from rising stream stages as a result of augmentation.

mum temperatures which normally occur between 3 p.m. and 4 p.m. at site 2 , water would have to be introduced between sites 6 and 7 before 11 a.m.

Intermittent pumping would be practical to improve stream conditions that are time-dependent, such as maximum or minimum stream temperatures, diurnal lows in DO concentrations, or low flows resulting from scheduled withdrawals. Conditions that are not time-dependent, such as stream volume (living space) or pollution, probably would not respond satisfactorily to intermittent pumping.

The water source may influence the pumping schedule. For example, an irrigation well may be used for augmentation when irrigation is not required, or a city's standby well may be available during periods of low demand. Also, if a well is located near a stream, intermittent pumping will cause less strearnflow depletion than continuous pumping. Economic factors alsc may favor intermittent pumpage.

TEMPER.ITURE

Temperature changes resulting from augmentation occurred in the study reach in spite of small initial differences between stream 
and ground-water temperatures. When the well discharge at $50^{\circ} \mathrm{F}$ $\left(10^{\circ} \mathrm{C}\right)$ entered the stream, the stream temperature at site 6 dropped from $59^{\circ} \mathrm{F}\left(15^{\circ} \mathrm{C}\right)$ to $56^{\circ} \mathrm{F}$ (about $13^{\circ} \mathrm{C}$ ). The water temperature at site 4 dropped $2^{\circ} \mathrm{F}$ (about $1^{\circ} \mathrm{C}$ ) about 5 p.m., and the temperature at site 2 dropped nearly $2^{\circ} \mathrm{F}$ (about $1^{\circ} \mathrm{C}$ ) about 8 p.m. Because pumping was continuous, no further rapid changes occurred until the end of the pumping, when a rise of $3^{\circ} \mathrm{F}$ (about $2^{\circ} \mathrm{C}$ ) was noted at site 6 , and rises of $2^{\circ}$ and $1^{\circ} \mathrm{F}$ $\left(1^{\circ}\right.$ and $\left.0.6^{\circ} \mathrm{C}\right)$ were noted at sites 4 and 2 , respectively, as stages fell.

A stream-temperature model (appendix) was developed as part of the study to predict downstream temperatures based on air temperature and water temperature at the upstream end of the study reach. The model was used to compare maximum stream temperatures during the test period to temperatures that would have occurred without augmentation (fig. 8). Temperature change becomes negligible about 1 mile below the augmentrition site for conditions experienced during the test period.

For more extreme conditions than those occurring during the test (such as might occur anytime from June through Sertember), the temperature change in the upper reach would be significantly greater (fig. 9), However, the distance that the change extends downstream would not be materially affected.

Because streamflow reduction as a result of ground-water withdrawals is possible (Weeks and Stangland, 1971, p. 154-172), the extreme case-no ground-water runoff in the study res?hwas also considered. Curves $C$ and $D$ in figures 8 and 9 show the temperature profile that would occur and the extent it would be improved with augmentation. For less than 100 percent reduction of ground-water runoff, the normal temperature profile would lie between curves $A$ and $C$, and the profile during augmentation would lie between curves $B$ and $D$. Under these extreme conditions temperature improvement extends farther downstream. Apparently, stream reaches with little ground-water runoff are more amenable to temperature improvement by augmentation with pumped ground water than are reaches with much ground-water runoff.

Minimum temperatures also may be a critical factor in trout habitat, and improvement would be significant when water temperatures approach $32^{\circ} \mathrm{F}\left(0^{\circ} \mathrm{C}\right)$ in winter (fig. 10). As in the former cases, improvement is more pronounced when groundwater runoff is low. The importance of ground-water runoff is noted by comparing curves $A$ and $C$. Water temperatures are maintained above $32^{\circ} \mathrm{F}\left(0^{\circ} \mathrm{C}\right)$ for an additional 0.9 mile when 


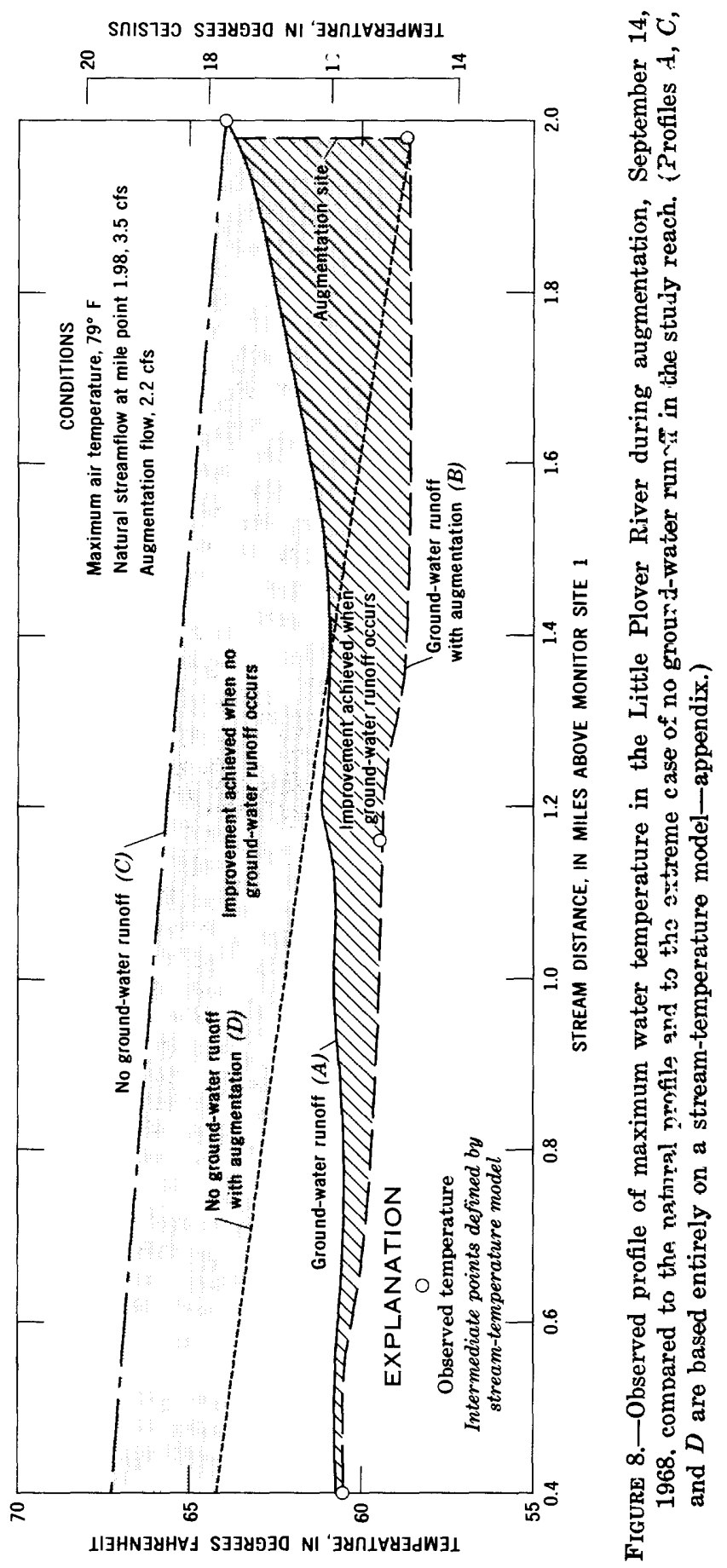




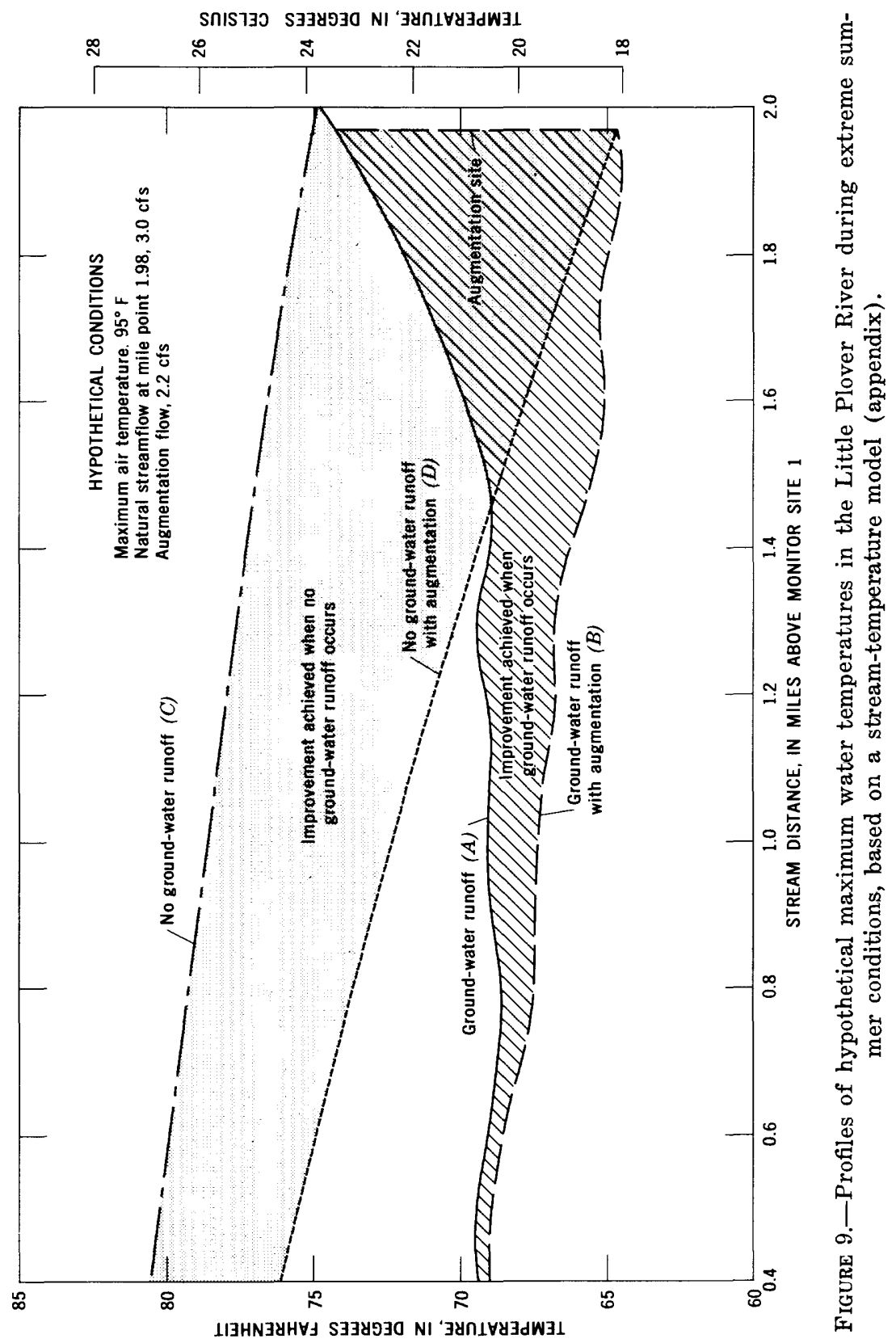




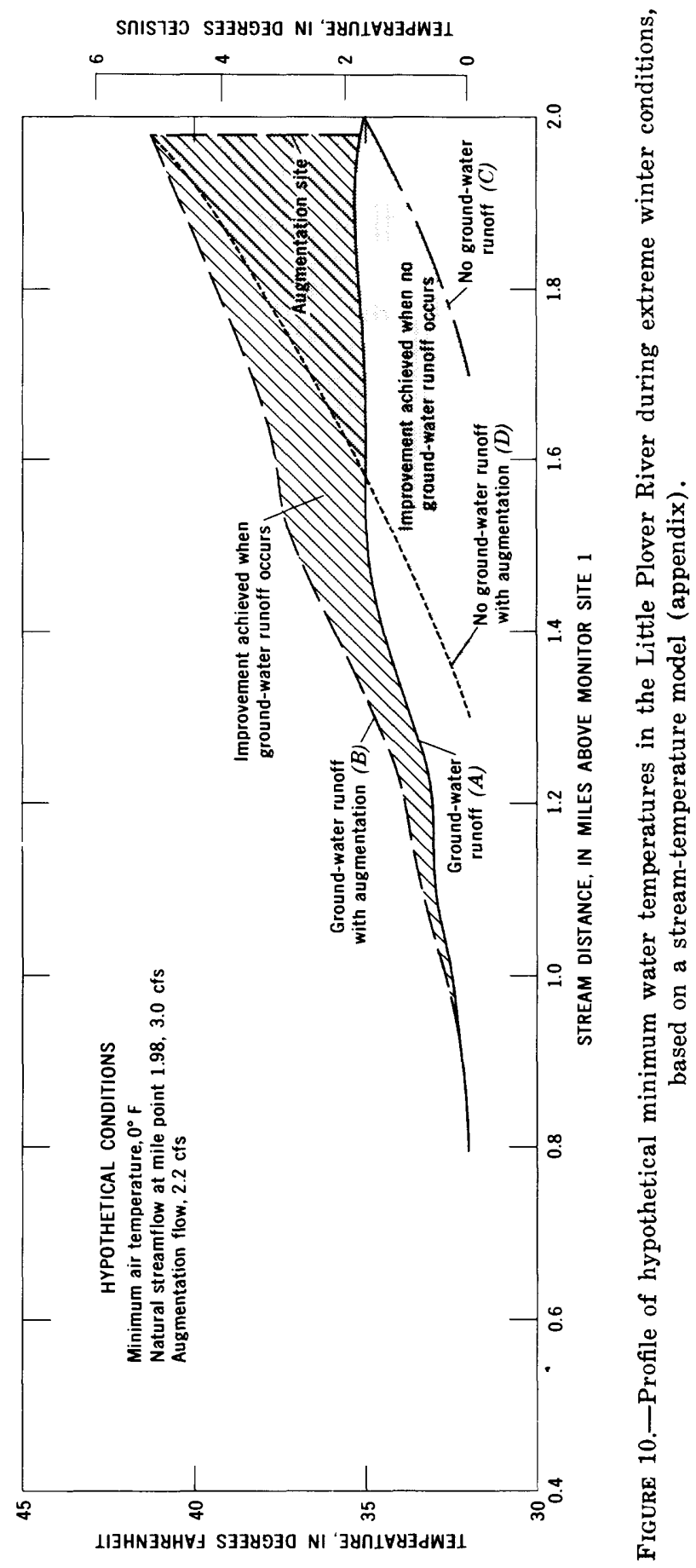


ground-water runoff occurs. The profiles are not drawn beyond the point at which they first reach $32^{\circ} \mathrm{F}\left(0^{\circ} \mathrm{C}\right)$ because tre response coefficient used in the predictive model is no longer valid. (The heat exchange required to freeze water is greater than that required to cool water before ice is formed.) However, this does not mean that the stream freezes at this point; ice may not exist for some distance downstream, and complete ice cover may not occur.

\section{DISSOLVED OXYGEN}

DO levels increased abruptly at each monitor site as augmentation began. Immediately before the augmenting flow arrived, DO had been between 8 and $9 \mathrm{mg} / \mathrm{l}$ and was decreasing. When augmentation started, it increased to $10 \mathrm{mg} / \mathrm{l}$. DO levels $\varepsilon$ t site 6 initially increased to slightly more than $11.0 \mathrm{mg} / \mathrm{l}$, but for the rest of the period it was within the same range as the levels at the other sites. DO at site 2 was maintained slightly higher, ranging between approximately 10.0 and $11.0 \mathrm{mg} / \mathrm{l}$ during the test period. DO levels at all sites decreased $1.0-1.5 \mathrm{mg} / \mathrm{l}$ as pumping ceased.

Because of the high natural DO levels in the Little Plover River during the study period, the effect of augmentation was slight. The increase in diurnal lows could not be measured directly but was probably less than $2 \mathrm{mg} / \mathrm{l}$ (fig. 11), and diurnal highs may even have been reduced. However, during periods when natural DO levels dropped below $7 \mathrm{mg} / \mathrm{l}$, the effect of augmentation probably would be more pronounced.

The diurnal variability in DO during augmentation was slight (fig. 11). Although the variability was less than that observed before augmentation, it is difficult to separate the effect of aug-

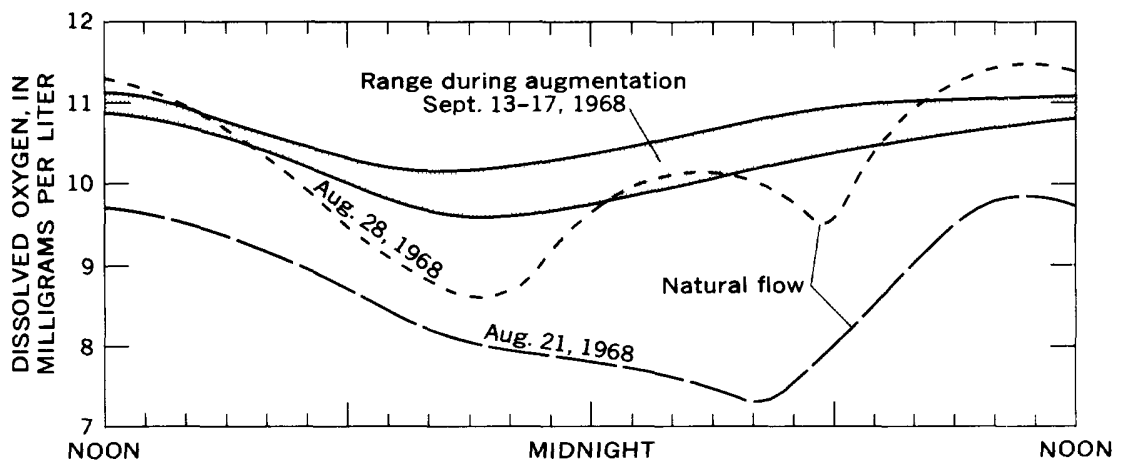

FIgURE 11.-Diurnal cycles of DO at monitor site 2 on the Little Plover River before and during augmentation. 
mentation from the effect of natural changes in the stream during the period between measurements.

The effectiveness of augmentation in a given situation could be predicted by determining the weighted mean DO concentration of the stream and of the augmenting flow. This may be a conservative estimate if pumpage is introduced into the stream as a jet of water, as in this study, because the additional turbulence created at the surface of the stream provides additionsl oxygenation at that point, as well as an improved mixing regimen for some distance downstream. This explains why DO levels were higher downstream from the discharge point than DO levels in either the streamflow above the augmentation site or in the well discharge.

Well water used for augmentation may have naturally low DO. Water from deep, regional systems is more likely to have low DO than water from shallow, local systems. Water having contact with organic or inorganic deposits that are in a reduced state usually will be devoid of DO. Such water may have material in solution in a reduced state that may deplete oxygen from the stream.

Water deficient in DO may require aeration if DO in the stream is to be maintained or improved. Adequate aeration may be accomplished simply by directing the well discharge into the stream as a jet of water, as in this study, or by a system of baffles or mechanical aerators.

CRITERIA FOR SITE SELECTION

SELECTION OF STREAM

Several factors should be considered in the choice of streams for augmentation. The size of the stream, the augmentation volume required, the availability and location of water sources, and the compatibility of the water quality of the augmenting flow with that of the natural streamflow should all be consicered after habitat problems are identified. Priorities may be established, in part, by consideration of these factors in the individual streams.

The size of the stream is critical because improvement of some stream characteristics depends upon the relative volumes of augmenting flow and natural streamflow. Most significant improvements usually are achieved when the augmenting flow is large relative to the natural streamflow.

The volume of augmentation required depends on the improvement sought and the existing streamflow. For temperature improvement the ratio of augmenting flow to the resultant combined streamflow is equal to the ratio of the desired temperature change to the difference between stream temperature and the tempera- 
ture of the augmenting flow. For example, to reduce maximum stream temperatures from $90^{\circ} \mathrm{F}\left(32^{\circ} \mathrm{C}\right)$ to $70^{\circ} \mathrm{F}\left(21^{\circ} \mathrm{C}\right)$ at the augmentation site, an improvement of $20^{\circ} \mathrm{F}\left(11^{\circ} \mathrm{C}\right)$, woulc require an augmentation flow, at $50^{\circ} \mathrm{F}\left(10^{\circ} \mathrm{C}\right)$, equal to 50 percent $(20 / 40$ or $11 / 22)$ of the resultant combined streamflow bolow the augmentation site. If natural streamflow is $10 \mathrm{cfs}$, the volume of water required is $10 \mathrm{cfs}(4,480 \mathrm{gpm})$.

The next step is to determine if it is possible to obtain the required volume of water for augmentation. An evaluation of general availability of water is presented in the hydrologic irvestigations atlases for Wisconsin, published by the U.S. Geological Survey. More detailed information for a specific location may be obtained from the U.S. Geological Survey, Madison, from the State Geologist in Madison, or from consulting firms or well drillers throughout the State.

The location of each problem stream should be evaluater in terms of water availability and of transmitting the water from the available source. Transmission costs may be significant if distances are great because the large volumes of water invclved require expensive transmission facilities. Flow losses, too, may be significant in long transmission lines. Wisconsin law prohibits interbasin transfer of water, a consideration in some situations.

Compatibility of the augmenting flow to natural streamflow also is necessary. Water of significantly different chemical composition introduced into the stream may create such problems as precipitation or oxidation-reduction. Furthermore, the existing aquatic biota represents a balance based on the existing water type, and significant changes in the water could upset this balance to the detriment of the entire stream.

\section{SELECTION OF AUGMENTATION SITE}

The augmentation site, relative to the stream reach selected for improvement, also must be carefully selected. Some improvements achieved by augmentation diminish rapidly below the discharge point, and others are significantly affected by stream characteristics. Temperature improvements diminish downstream, whereas DO improvement does not appear to be directly affected by the stream distance traveled. Dilution, dependent on stream volume, is also relatively independent of the discharge point.

For temperature improvement, the augmenting flow should be introduced as close to the upstream end of the problem reach as possible. In the Little Plover River temperature changes became insignificant more than 1 mile downstream from the discharge point. Thus, if the problem reach is long, a system of multiple 
augmentation sites or multiple wells may be required to achieve the desired temperature improvement.

Location of the augmentation site is not as critical in terms of DO improvement in the problem reach. In the Little Plover River, DO changes extended essentially undiminished more than 2 miles downstream. However, DO improvement depends upon the ratio of augmenting flow to natural streamflow, and in gairing streams the improvement probably will decrease downstream as the ratio of augmentation flow to natural stream flow diminishes. Thus, greatest DO improvement will be obtained in str?am reaches that are neither gaining nor losing and where the augmentation flow is retained.

Other stream improvements such as increased living space and improved water quality also are accomplished best in reaches where the augmentation flow is retained. To assure retention of augmenting flow, selection of a gaining reach of the stream is necessary to prevent losses when the stream stage rises. Although most trout streams are gaining streams, the longer and larger ones may have local losing reaches.

Retention of augmentation fiows can be infiuenced by the location of the supply well. Wells located near the stream may reduce streamflow by intercepting natural ground-water runoff to the stream, and additional streamflow reduction will crcur if the wells induce recharge from the stream. The prefersble location for wells is far enough from the stream to prevent induced recharge. Where wells near the stream are necessary, a location downstream from the augmentation site would allow increased flow below the discharge point. However, flow would again decrease to near natural conditions in the reach afferted by the well. Wells also might be located upstream if the upstream reaches are normally unsuitable as trout habitat. Although streamflow would be reduced in the upstream reach, effectiveness of augmentation downstream might be enhanced, as discussed below.

Although most aspects of improvement depend upon retention of augmenting flow, the stream-temperature regimen is an exception. When streamflow volume decreases in a losing reach, subsequent ground-water runoff will have a more prono'nced effect on water temperature because of the increased ratio of groundwater runoff to natural streamflow.

In summary, improvements in stream temperature, DO levels, living space, and water quality can be provided by streamflow augmentation. However, it is essential to evaluate each stream in terms of the improvements sought and the potential for 
achieving these goals. Equally important in the final choice, the feasibility of providing augmentation in the reach chosen should be considered.

\section{BLACK EARTH CREEK SETTING \\ HISTORY OF TROUT HABITAT}

After considering several trout streams, the Wisconsin Department of Natural Resources proposed Black Earth Creek for the second phase of the study (fig. 1). Classified as a Class I trout stream (Wisconsin Conservation Department, 1966, p. 28), the stream is capable of supporting brook, rainbow, and brown trout. Naturally reproduced trout of each type have been found in the stream.

However, Black Earth Creek has experienced habitat problems in the past. The first serious problem occurred after a millpond was created within the city limits of Cross Plains. The pond, about one-half mile long, seriously affected the habitat formerly provided in this reach (R. J. White, written commun., 1964). Water temperatures in the pond increased, and siltation and growth of algae combined to degrade the habitat. The trout habitat downstream from the pond also was adversely affected.

A program of habitat protection and improvement was initiated by the Wisconsin Conservation Department (presently the Dapartment of Natural Resources) in 1949. The program included streambank fencing, channel modification, tree planting, and removal of the millpond dam. The program was essentially completed by 1956. The trout population responded to the program, gradually increasing as the habitat improved. The greatest trout populations were found in 1961 and 1962 (R. J. White, written commun., 1964).

More recently the habitat downstream from Cross Plains has been degraded by effluent from the sewage-treatment plant. Discharge from the primary treatment facility caused high nutrient levels in the stream. Initially this resulted in abundant aquatic vegetation and other aquatic biota, which in turn supported a large population of trout (R. J. White, oral commun., 1969). However, a combination of clear, hot days and nights, low summer streamflow, and heavy oxygen demand from the aquatic vegetation and the sewage effluent created critically low DO levels and resulted in fish kills in the summers of 1963 tr rough 1967.

Secondary treatment facilities were put into operation at the sewage-treatment plant in 1968. Since that time no fish kills have been observed. However, current studies ( $O$. M. Brynildsc $n$ and 
J. W. Mason, written communs. 1969) indicate that populations of wild brown trout still are depressed in the problem reach, which begins at the sewage-treatment plant and extends about $11 / 2$ miles downstream.

Low DO has been a critical factor in the trout habitat in Black Earth Creek. Studies as recent as 1968 determined that DO levels fell below $5 \mathrm{mg} / \mathrm{l}$ in the problem reach. Under more extreme conditions DO may have been even lower. Because optimum DO levels for trout are $7 \mathrm{mg} / \mathrm{l}$ or above, improvement in minimum DO levels was desirable.

Stream temperatures are not known to have reached critical levels for trout in the study reach; even in extreme summers, stream temperatures seldom reached $70^{\circ} \mathrm{F}\left(21^{\circ} \mathrm{C}\right)$.

\section{GEOLOGY AND HYDROLOGY OF AREA}

Glacial outwash deposits are a major aquifer in Rlack Earth Creek basin, as in the Little Plover River basin. Hovrever, sandstones of various ages are also a significant source of water. For the purposes of this study the standstone and the cutwash are treated as a single water source. The basin is underlain by relatively impermeable, deeply buried, crystalline rock of Precambrian age.

Ground-water runoff makes up more than 80 per?ent of the flow in Black Earth Creek and maintains relatively stable streamflow throughout the year. Average discharge at the U.S. Geological Survey's gaging station at Black Earth was $28.6 \mathrm{cfs}$ during the period 1954-68 and ranged from $4.8 \mathrm{cfs}$ (the result of freezup) to $1,750 \mathrm{cfs}$. Springs in the headwater area of the stream are common, and many have spring ponds with permanent channels leading to the stream.

\section{CONCURRENCE WITH SITE-SELECTION CRITERIA}

In Black Earth Creek the habitat problem is basically one of low DO levels. Recent changes in the sewage-treatment plant and residual effects from the former millpond, however, make the situation somewhat complex. Natural streamflow is greater than in the Little Plover River but is not beyond the reasonable limits of augmentation. Ground water is readily available. The quality of ground and stream water is compatible, because tho source of most streamflow is ground-water runoff.

The reach chosen for the study extends from a point above the gravel pit downstream to a point near Salmo Pond (fig. 12). This includes the problem reach or "zone of pollution" icentified by the Wisconsin Department of Natural Resources (Brynildson, 1967). In addition, it includes the limits of the former millpond. 





Gravel pits in the headwater area were selected as the source of ground water for augmentation. Water from the gravel pits was discharged into a stream channel tributary to the upper reaches of Black Earth Creek. Because temperature improvement was not required in the problem reach, no improvement in the transmission facilities was considered. Discharge of ground water to the stream was a normal part of the gravel-pit operation, and no costs were incurred.

The point at which the gravel-pit discharge enters the stream satisfies the criteria for volume retention, but it is not well located to provide temperature improvement or improvement in DO levels in the problem reach. Black Earth Creek is a gaining stream and retention of augmenting flows was expected. Improvement in DO levels just below the augmentation site also could be expected. Because of increasing natural streamflow, however, the DO improvement was expected to diminish downstream.

\section{APPLICATION}

\section{IMPROVEMENTS SOUGHT}

Of the improvements sought, DO, which had beer a critical factor in the stream, was expected to show greatest change. Natural streamflow in the headwater area during low-flow periods averaged 1-2 cfs. With augmentation volumes of about $2 \mathrm{cfs}$, the DO just downstream from the discharge point was expected to be approximately midway between the concentration in the stream and in the gravel-pit discharge. DO in the stream ranged from 5 to $10 \mathrm{mg} / \mathrm{l}$, and in the gravel-pit discharge it ranged from 8 to $10 \mathrm{mg} / \mathrm{l}$. With augmentation the minimums were expected to be maintained at $7 \mathrm{mg} / \mathrm{l}$ or above. If the improvement could be maintained through the problem reach, DO levels vould be as much as $2-4 \mathrm{mg} / 1$ higher at individual points.

Living space in the upper reaches was expected to increase significantly because of the large volume of augmenting flow (more than $2 \mathrm{cfs}$ ) relative to normal streamflow. However, information on trout populations in the headwater area was not available, and the response of the trout in this area to improved conditions could not be determined.

Changes in minimum stream temperatures were expected because of the large volume and relatively high temperature of the augmenting flow. Gravel-pit operations warmed the discharge water to between $60^{\circ} \mathrm{F}$ and $70^{\circ} \mathrm{F}\left(16^{\circ}\right.$ and $\left.21^{\circ} \mathrm{C}\right)$, and because maximum stream temperatures also were typically within this range, little change in maximum temperatures was expected. 


\section{PHYSICAL SETUP OF MONITORING}

Temporary stream-gaging stations were established at six sites in the study area (fig. 12). The gage at monitor site 1 was above the discharge point and provided information on the natural streamflow. The remaining five gages and the U.S. Geclogical Survey gage near Black Earth provided information on streamflow as it was affected by augmentation.

Water-temperature recorders were located above, within, and below the problem reach (fig. 12). Additional water-temperature data were collected above and below the augmentation site at various times during the study. Air temperature was recorded at monitor site 6 .

A recording DO meter was located below the sewage-trestment plant at the point corresponding to the former low in the DO profile, and additional DO measurements were made intermittently throughout the study reach. The normal DO level of the ground water was determined from measurements obtained in the gravel pit and in several springs.

Several water-quality samples were analyzed to assure ccmpatibility of the augmenting flow and the stream water. Ground-water samples were taken at the gravel pit and at the manmade ponds (dug below the water table) downstream from the sewage-treatment plant. Surface-water samples were taken at three lo?ations in the stream. The results of the analyses are presented in table 1. As was expected the quality of ground water and stream water was essentially the same.

\section{PROCEDURE}

Ground water pumped from the gravel pit was used to augment the natural flow of Black Earth Creek. Water was pumped to the stream to lower water levels in the gravel pit during periods when high water levels hindered plant operation. More pumpage was required to maintain satisfactory water levels early in the summer than later, when water levels decline naturally. The pump delivered a continuous discharge of $1,100 \mathrm{gpm}(2.3 \mathrm{cfs})$ of water to the stream from June 26 to the end of July. During the $A$ ugustOctober period, when less pumpage was required to lower water levels in the gravel pit, the pump discharged $1,100 \mathrm{gpm}$ to the stream from approximately $6 \mathrm{p} . \mathrm{m}$. every day until 8 a.m. the following morning.

Streamflow, water and air temperatures, and DO levels were monitored during the test period. As in the Little Plover River phase of the study, stage-discharge relationships were used to define streamflow. Recording thermometers provided continuous 
TABLE 1.-Chemical analyses of water from Black Earth Creek, from manmade ponds below the sewage-treatment plant, and from the gravel pit pond used for augmentation

[All values are in milligrams per liter except specific conductance and pH, which are given in their standard units]

\begin{tabular}{|c|c|c|c|c|c|}
\hline \multirow{2}{*}{$\begin{array}{l}\text { Chemical constituent } \\
\text { or } \\
\text { physical property }\end{array}$} & \multicolumn{5}{|c|}{ Point and date of collection (1969) } \\
\hline & $\begin{array}{c}\text { Gravel pit, } \\
\text { November } \\
18\end{array}$ & $\begin{array}{l}\text { Manmade } \\
\text { ponds, } \\
\text { October 2 }\end{array}$ & $\begin{array}{l}\text { Monitor } \\
\text { site 1, } \\
\text { October 2 }\end{array}$ & $\begin{array}{l}\text { Monit }>\mathbf{r} \\
\text { site 2, } \\
\text { October 2 }\end{array}$ & $\begin{array}{c}\text { Monitor } \\
\text { site 4, } \\
\text { October } 2\end{array}$ \\
\hline Silica $\left(\mathrm{SiO}_{2}\right)$ & 17 & 11 & 16 & 21 & 28 \\
\hline Iron $(\mathrm{Fe})$ & .03 & .17 & .06 & .06 & .06 \\
\hline Manganese $(\mathrm{Mn})$ & .03 & .16 & .12 & .08 & .08 \\
\hline Calcium $(\mathrm{Ca})$ & 54 & 54 & 39 & 67 & 69 \\
\hline Magnesium (Mg) & 32 & 33 & 33 & 33 & 33 \\
\hline Sodium $(\mathrm{Na})$ & 4.1 & 4.4 & 4.4 & 3.9 & 8.2 \\
\hline Potassium (K) & 1.0 & 1.1 & 1.6 & 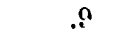 & 1.2 \\
\hline Sulfate $\left(\mathrm{SO}_{4}\right)$ & 18 & 18 & 18 & 14 & 15 \\
\hline Chloride ( $\mathrm{Cl}$ ) & 4.0 & 5.0 & 7.0 & 4.0 & 10 \\
\hline Fluoride (F) & .1 & .2 & .1 & .1 & .2 \\
\hline Nitrate $\left(\mathrm{NO}_{3}\right)$ & 6.3 & 7.3 & .3 & 6.0 & 11 \\
\hline Total phosphorus $\left(\mathrm{PO}_{4}\right)$ & .00 & .31 & .89 & .17 & 1.7 \\
\hline Dissolved solids & 272 & 277 & 243 & 306 & 331 \\
\hline Hardness as $\mathrm{CaCO}_{3}$ & 266 & 270 & 233 & 303 & 308 \\
\hline Total alkalinity as $\mathrm{CaCO}_{3}$ & 248 & 254 & 208 & 284 & 290 \\
\hline $\begin{array}{l}\text { Specific conductance } \\
\left(\text { micromhos at } 25^{\circ} \mathrm{C}\right) \text {. }\end{array}$ & 492 & 488 & 437 & 548 & 581 \\
\hline pH & 7.8 & 7.5 & 8.2 & 7.7 & 7.7 \\
\hline
\end{tabular}

records of water and air temperatures. DO was recorded at monitor site $\mathbf{5}$.

Additional streamflow data were provided by a series of discharge measurements made during a period of base flow in the winter of 1969 and by analysis of streamflow data from the temporary gaging stations. The results agree well with data obtained in 1958 (Cline, 1963, p. C20) and in 1964 (fig. 13).

Areas of ground-water runoff were determined from streamtemperature data for May 1970. Air temperatures ranged from $77^{\circ}$ to $85^{\circ} \mathrm{F}\left(25^{\circ}\right.$ to $\left.30^{\circ} \mathrm{C}\right)$ during the period required to traverse the length of the stream. Ground-water temperature was constant at $50^{\circ} \mathrm{F}\left(10^{\circ} \mathrm{C}\right)$, and changes in stream temperature were analyzed to indicate reaches of ground-water runoff (fig. ..4). Positive slopes in the profile indicate rising stream temperatures in response to the warmer air temperature. Less positive or negative slopes indicate stream-temperature response to inflow of cooler ground water. The modified streamflow profile, based on the temperature data, is included in figure 13.

Supplementary information on DO levels in Black Earth Creek was obtained from several DO profiles, and intermittent measurements of DO levels in ground water were obtained from ponds and a few springs. DO levels in ponds containing aquatic plants and algae showed significant diurnal variations ranging from 7 to 


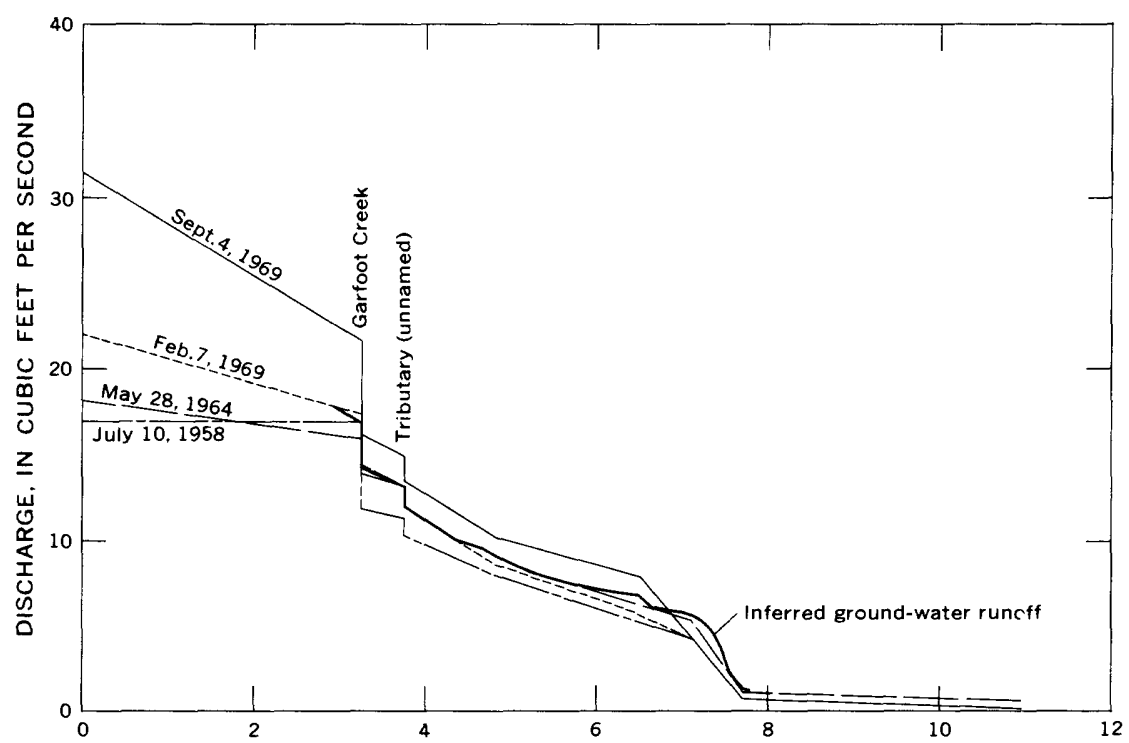

STREAM DISTANCE, IN MILES ABOVE STREAM-GAGING STATION AT BLACK EARTH

Figure 13.-Measured ground-water runoff and tributary inflow to Black Earth Creek, and inferred ground-water runoff based on analysis of stream temperature, May 1970.

$14 \mathrm{mg} / \mathrm{l}$. However, DO levels in the springs were constant at approximately $6.5 \mathrm{mg} / \mathrm{l}$.

A time-of-travel study was conducted in 1969 during base-flow conditions. Fluorescent dye was injected into the stream at mile point 7.04, and its rate of travel through the stream was traced with a portable fluorometer (fig. 15). The leading edge of the dye preceded the peak by as much as $1 \frac{1}{2}$ hours. The significance of time of travel during periods of intermittent pumpage is discussed later in this report.

\section{EVALUATION \\ DISCHARGE}

Augmenting flows were retained throughout the study roach. An initial increase of $2.3 \mathrm{cfs}$ was noted at each monitor site. and apparently it did not diminish with time. Augmenting flows were retained, undiminished, as far downstream as the gage at Black Earth, where fluctuations of nearly $2 \frac{1}{2} \mathrm{cfs}$ represented the amount introduced 7.75 miles upstream.

Living space increased significantly in the headwater area. However, as in the Little Plover River phase of the study, the changes in volume, cross-sectional area, and stream depth only indicate possible increases in living space. 


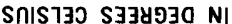

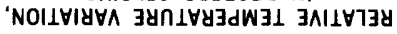

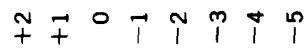



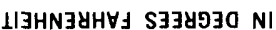

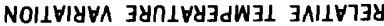

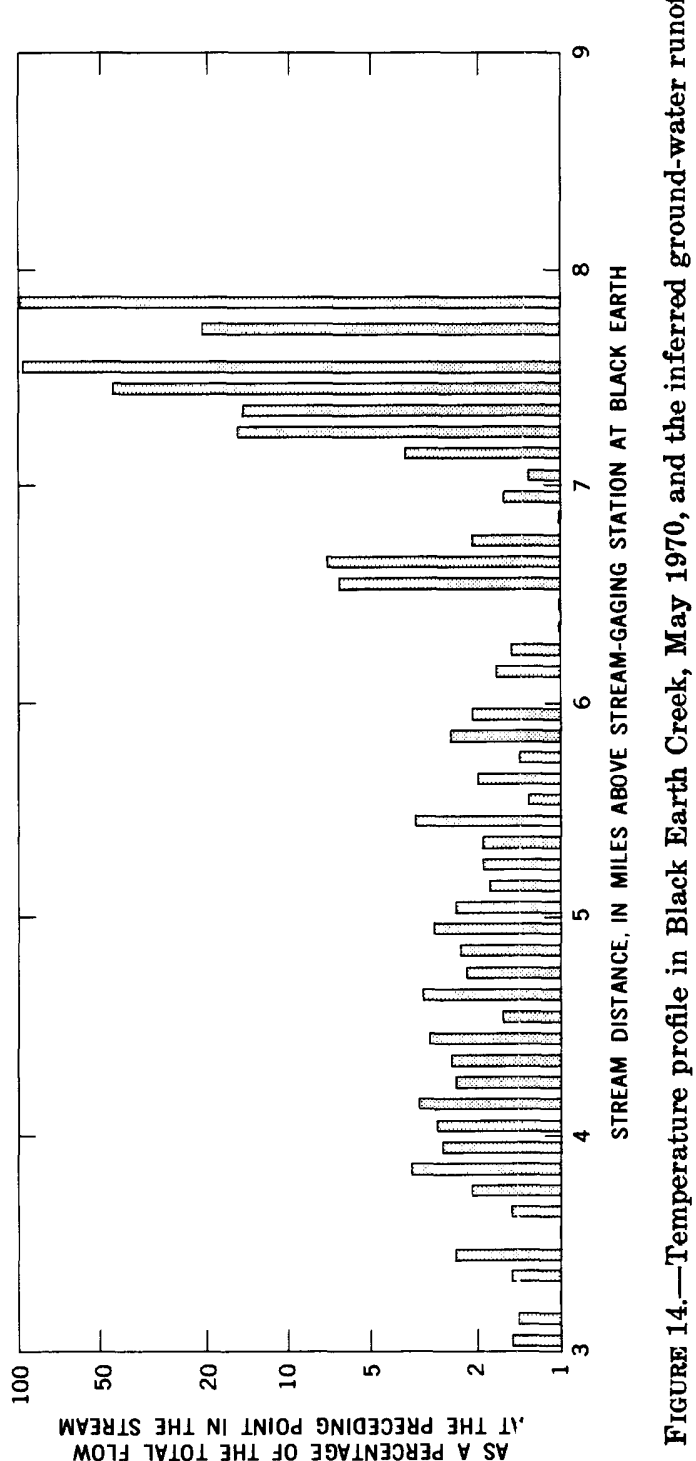

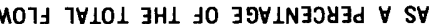
IJONกY \& 


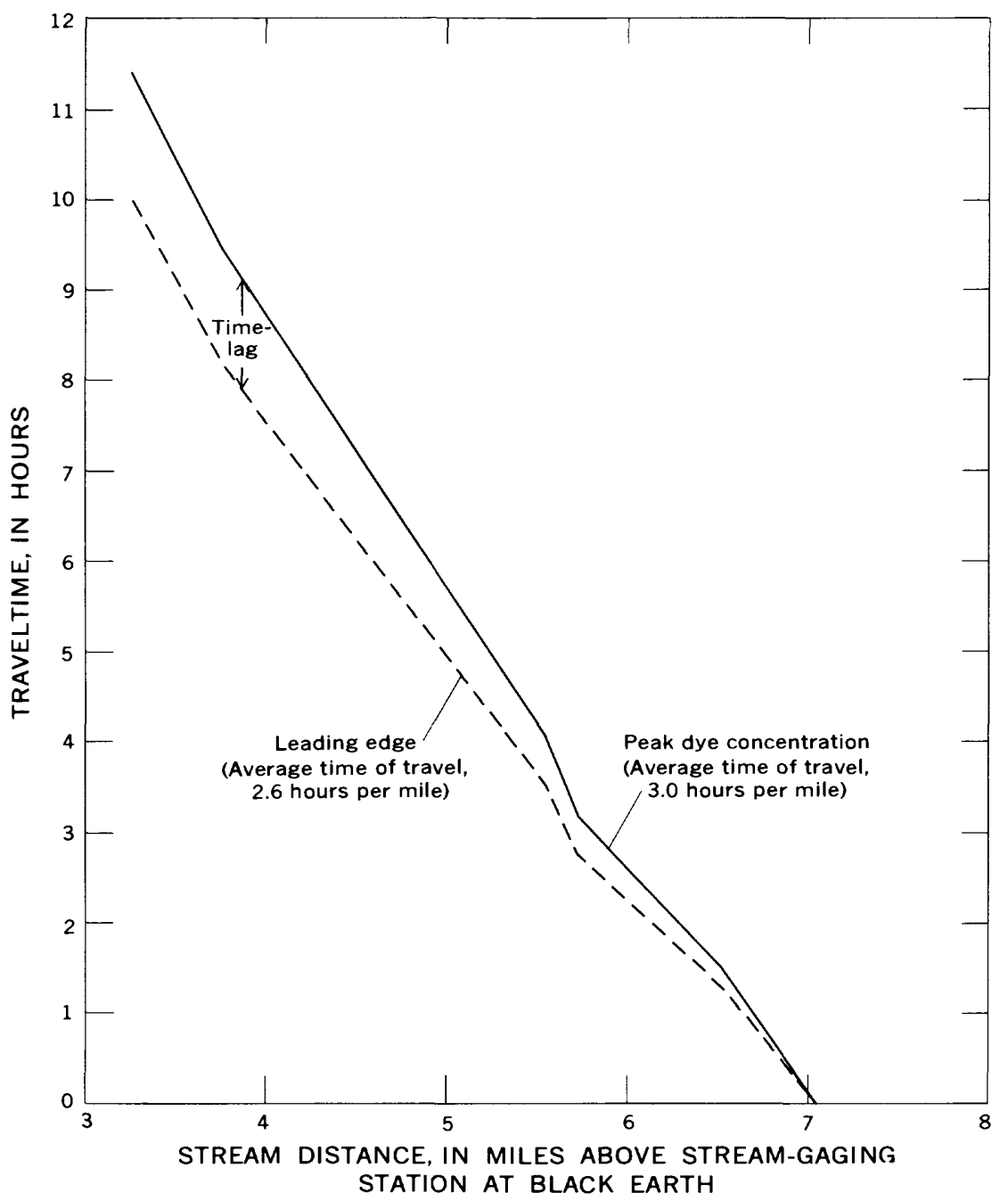

Figure 15.-Time of travel and lag between leading edge and peat of dye concentration in Black Earth Creek.

Streamflow volume increased 100-200 percent just below the augmentation site. The percentage decreased rapidly downstream as natural streamflow increased from ground-water runoff (fig. 13). The increase was only 20 percent at monitor site 2 and less than 10 percent at monitor site 6 .

Cross-sectional areas increased only a small amount, apparently because velocity increased more rapidly than area with increases in flow. Increases in the headwater area were less than 50 percent, and at the lower end of the study reach increases were less than 
10 percent. These percentages represent increases in stallow riffle areas only. Changes in the deeper pools would be much smaller.

Changes in stream depth also were greatest in the headwater area. Depths in shallow riffles 500 feet below the augmentation site increased 0.1-0.2 foot, nearly 25 percent. Between monitor sites 2 and 6, however, increases were less than 0.1 foot and represent an increase of 5-10 percent in reaches typically 1.0-2.0 feet deep. Again, these figures represent changes in shallow reaches of the stream only, and changes in deeper pools would be negligible.

\section{TEMPERATURE}

Minimum temperatures increased in response to augmentation with $60^{\circ}-70^{\circ} \mathrm{F}\left(16^{\circ}-21^{\circ} \mathrm{C}\right)$ water. Figure 16 presents comparative profiles of minimum temperatures during natural flow and during intermittent augmentation. Minimum temperatures were raised nearly $3^{\circ} \mathrm{F}\left(2^{\circ} \mathrm{C}\right)$ at mile point 7.04 and $2^{\circ} \mathrm{F}\left(1^{\circ} \mathrm{C}\right)$ at mile point 6.52 (monitor site 2 ). Temperature change during intermittent augmentation, however, became negligible beyond mile point 5.4 because minimum temperatures occurred before the augmentation flow arrived.

Augmentation may be more beneficial during winter when minimum stream temperatures approach $32^{\circ} \mathrm{F}\left(0^{\circ} \mathrm{C}\right)$. Hcwever, the temperature of the augmenting flow during the winter probably would be near $50^{\circ} \mathrm{F}\left(10^{\circ} \mathrm{C}\right)$, the normal ground-water temperature. The effectiveness of augmentation in the headvater area during this period would be limited because significant amounts of ground-water runoff in this area prevent the occurrenco of critical stream temperatures during extreme climatic conditiors (fig. 17).

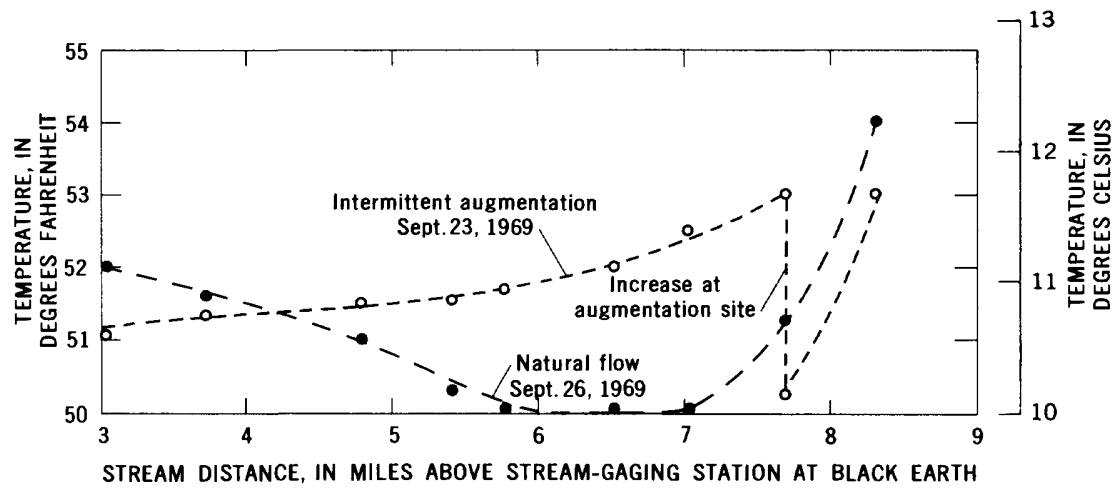

Figure 16.-Profile of minimum water temperatures in Black Earth Creek during intermittent augmentation (Sept. 23) compared to temperatures during natural flow (Sept. 26). 


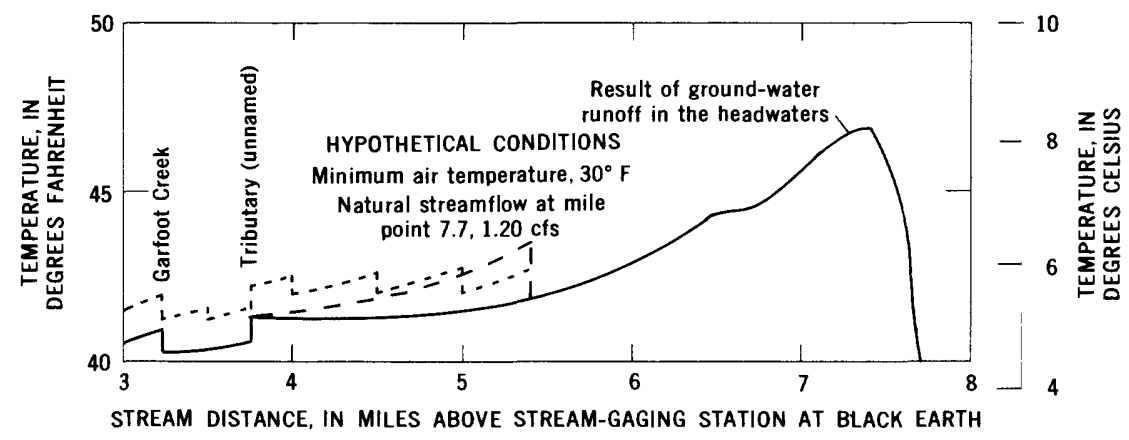

\section{EXPLANATION}

With augmentation of $2 \mathrm{cfs}$ (at $\left.50^{\circ} \mathrm{F}\right)\left(10^{\circ} \mathrm{C}\right)$
introduced below sewage-treatment plant at
mile point 5.4
With augmentation of $1 \mathrm{cfs}$ (at $\left.50^{\circ} \mathrm{F}\right)\left(10^{\circ} \mathrm{C}\right)$
introduced below sewage-treatment plant and
also at mile points $5.0,4.5,4.0$, and 3.5

Figure 17.-Profiles of hypothetical minimum water temperatures in Black Earth Creek during natural flow and in response to augmentation at one or several sites, based on a stream-temperature model (appendix).

The effectiveness of alternate augmentation schemes ce.n be estimated from the stream-temperature model and observed temperature and streamflow data. (appendix). Temperature data obtained in Black Earth Creek were used to determine coefficients for the model developed in the first phase of the project. Alternate schemes, such as introducing water at the upper end of the problem reach or at multiple-discharge points within the prcblem reach, were evaluated with the model. Resultant maximum and minimum stream-temperature profiles are presented in figures 17 and 18. Augmentation from multiple-discharge points through the stream reach is most effective in temperature improvement for long distances downstream. However, neither approach provides significant temperature change, primarily because natural stream temperatures are not critical, and the natural strear flow is relatively large compared to the augmentation flows. Hence, augmentation for temperature improvement in Black Earth Creek is not feasible except as a supplementary benefit obtained with desired improvement in DO levels.

\section{DISSOLVED OXYGEN}

Significant improvement in minimum DO was observed kalow the augmentation site in response to augmentation. However, 


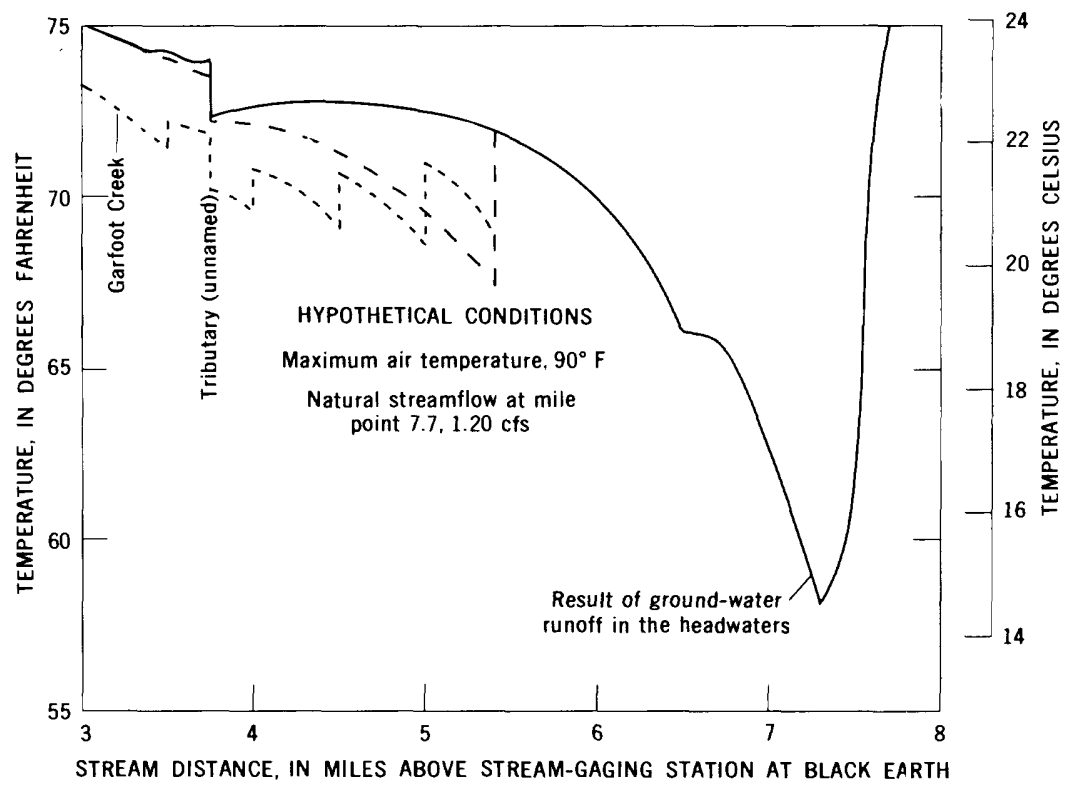

EXPLANATION

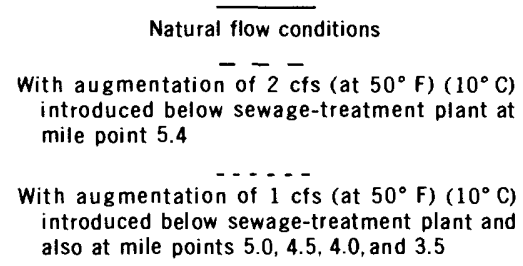

FIGURE 18.-Profiles of hypothetical maximum water temperatures in Black Earth Creek during natural flow and in response to augmentation at one or several sites, based on a stream-temperature model (appendix).

lowest reported DO levels had occurred 0.7 mile below the sewagetreatment plant (fig. 19), at monitor site 5. DO was as low as $2 \mathrm{mg} / \mathrm{l}$ in 1963 and 1964 (Schraufnagel and others, 1964). Minimum DO levels were as low as $3 \mathrm{mg} / 1$ in 1967, and might have been low again in 1968 except that oxygenated water from rain prevented DO from dropping below $5 \mathrm{mg} / 1$ (fig. 20). During 1969 minimum recorded DO levels did not fall below app roximately $7 \mathrm{mg} / \mathrm{l}$. However, because pumpage had been continuous during the critical summer period, natural DO levels could not be measured directly.

Mass-balance techniques were used to estimate the DO change in the problem reach in response to augmentation. With the ob- 


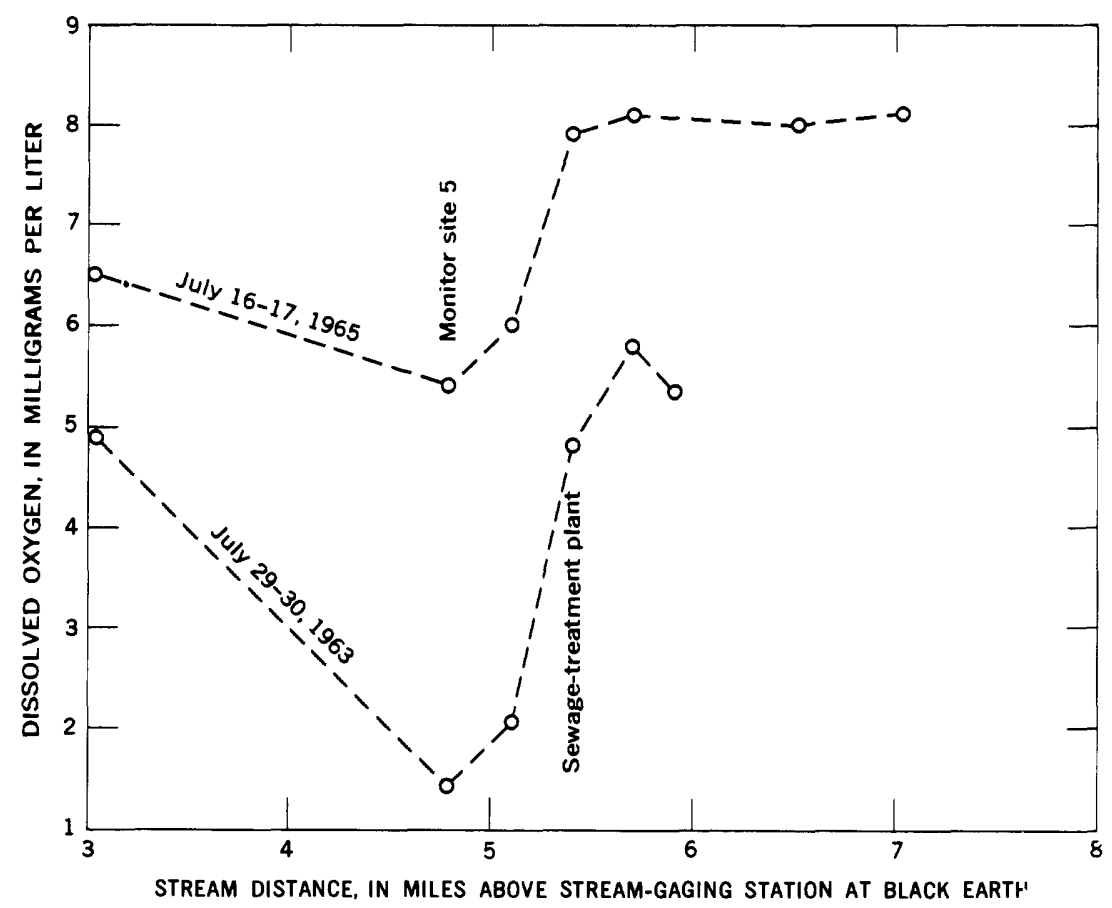

Figure 19.-Selected DO profiles in Black Earth Creek before improvement in sewage-treatment facilities (1968) and augmentation (1969). (Data from Schraufnagel and others, 1964, and D. A. Wentz, written commun., 1968.)

served minimum DO of $7 \mathrm{mg} / 1$ at monitor site 5 , where the augmentation flow of $2 \frac{1}{2}$ cfs represented an increase of approximately 25 percent (fig. 13), the natural DO is given by the relation:

$$
\text { Natural DO }=\frac{(1.25)(7 \mathrm{mg} / \mathrm{l})-(0.25)(10 \mathrm{mg} / \mathrm{l})}{1.00}
$$

Hence, the minimum natural DO concentration was slightly greater than $6 \mathrm{mg} / 1$, and the change in response to augmentation was an increase of approximately $1 \mathrm{mg} / \mathrm{l}$. During periods when natural streamflow in the problem reach was lower (5-8 cfs), and if natural DO levels were in the range of $3-5 \mathrm{mg} / 1$, the imrrovement in response to augmentation might have been $2 \mathrm{mg} / 1$ or more.

Mass-balance techniques provide reasonable estimates of DO but do not allow for changes in the reoxygenation characteristics of the stream during augmentation. The rate of reoxygeration increases with increased temperature and with the increased mixing rates as stream velocity, turbulence, and surface exp-sure increase (Fair and Geyer, 1965, p. 841-842). 


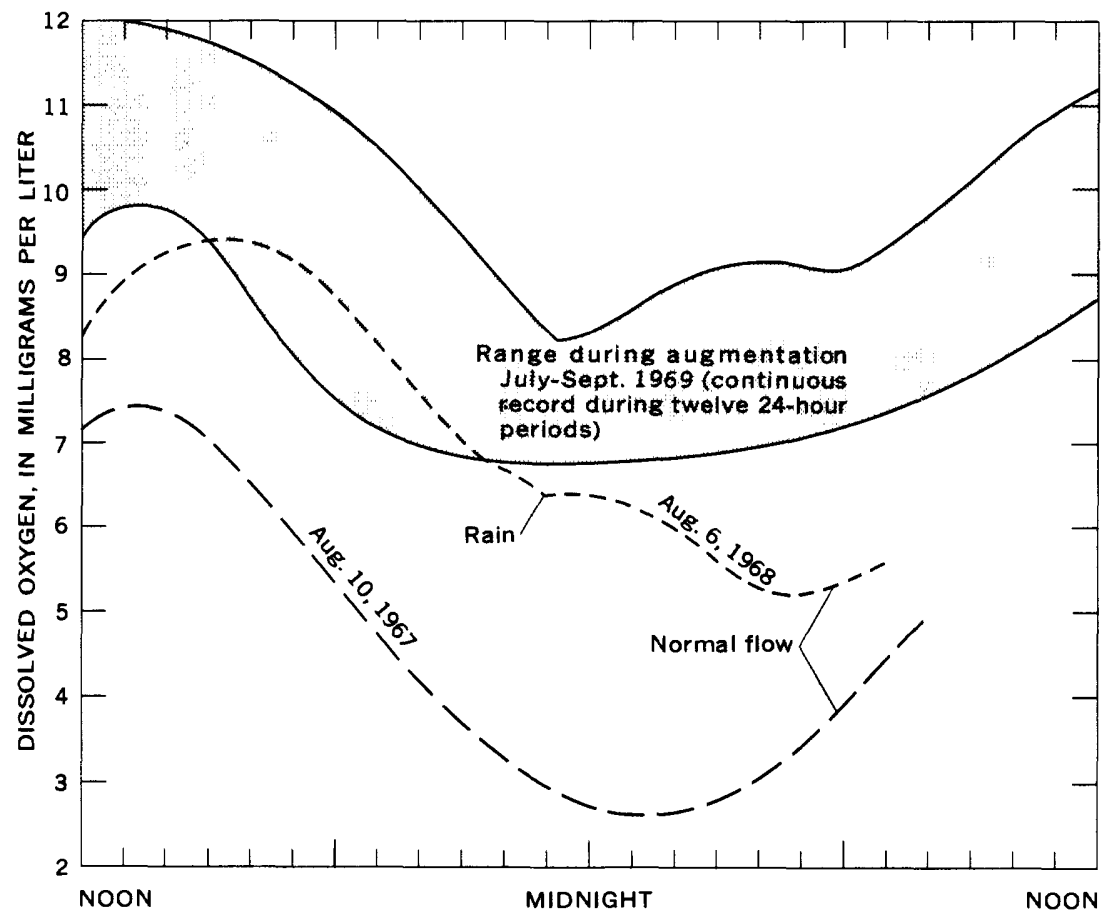

FiguRe 20.-Diurnal cycle of DO observed in Black Earth Cresk at monitor site 5 during augmentation in 1969 compared to observations obtained by the Wisconsin Department of Natural Resources in 1967 and 1968.

Comparative profiles of minimum DO levels for 2 days during the period of intermittent augmentation are presented in figure 21. DO levels were raised approximately $2 \mathrm{mg} / 1$ at the augmentation site, but the improvement decreased rapidly kayond mile

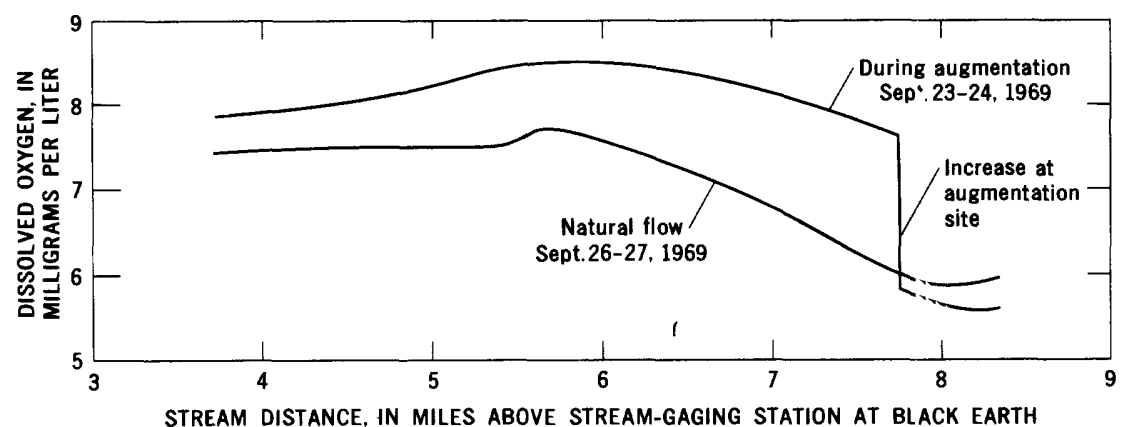

FIGURE 21.-Profiles of minimum DO levels in Black Earth Creek during intermittent augmentation and during natural flow. 
point 5 because, as a result of timelag, minimum DO levels occurred before the augmentation flow arrived. (Minimum DO levels typically occur between midnight and 6 a.m.) The normal curve (September 26-27) reflects low oxygen demand becruse of decreased activity of the stream biota late in the growing season. Improvement achieved during midsummer probably was even more significant.

Time of travel of the stream water is important during roriods of intermittent augmentation. Figure 22 shows the DO cycle at monitor site 5 on September 23-24 during the period of intermittent augmentation. DO levels began to rise as the augmenting flow arrived, but maximum improvement was not achieved until the full augmentation flow reached the site about 3 a.m. Note, however, that DO levels initially were less than $9 \mathrm{mg} / \mathrm{l}$ about 6 p.m., 9 hours before full improvement occurred. If augmertation had begun earlier or had been continuous, DO levels might have remained at or above $9 \mathrm{mg} / 1$ during the 24-hour period.

Improvement provided by continuous augmentation may be inferred from the DO cycle observed on July 26-27 (fig. 23). Response to augmentation is apparent as early as 6 p.m., ard DO levels remain constant until the normal morning rise occurs. The lower part of the shaded area enclosing the 1969 data in figure 20 is similar to the curve in figure 23 and apparently reflects the DO concentrations during the period of continuous augmentation. The upper part of the shaded area is similar to the curve in figure 22
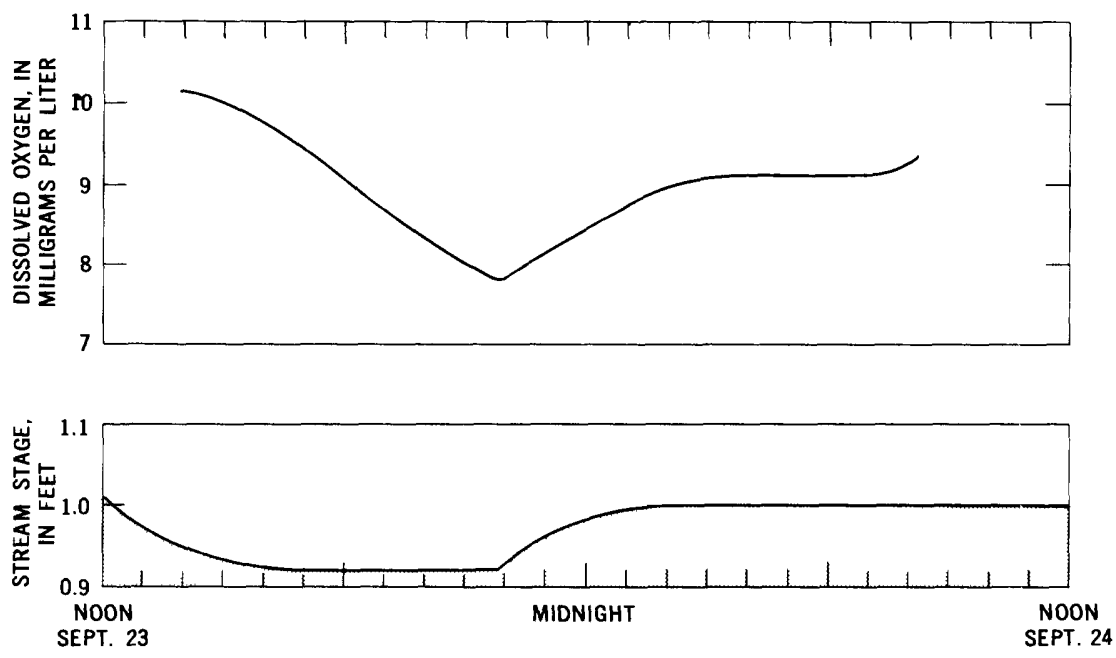

FiguRE 22.-Diurnal DO cycle and stream-stage fluctuations in Black Earth Creek at monitor site 5, September 23-24, 1969, in response to intermittent augmentation. 


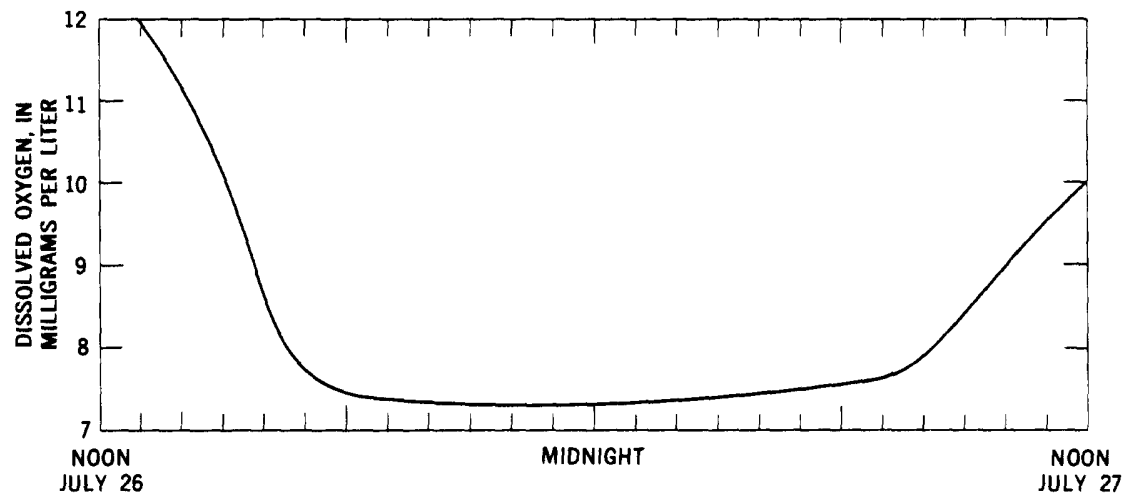

Figure 23,-Diurnal DO cycle in Black Earth Creek at monitor site 5, July 26-27, 1969, during continuous augmentation.

and apparently reflects DO concentrations during the period of intermittent augmentation.

Continuous augmentation during the critical summer period provided improved DO levels as far downstream as site 5, 3 miles below the augmentation site. If pumpage had been intermittent (between 6 p.m. and 8 a.m.), improvement probably would have been negligible more than 2 miles below the augmentation site because critical DO levels would have occurred before the augmenting flow arrived. To improve DO levels by interrittent augmentation in long stream reaches where traveltime kecomes significant, suitable pumping schedules or multiple augmentation sites may be required. In such cases continuous augmentation may be more desirable than intermittent augmentation.

\section{RECOMMENDATIONS}

\section{APPLICATIONS}

Significant habitat improvement through streamflow augmentation may be obtained in many trout streams throughout Wisconsin. Extreme temperatures and DO levels, which may result in fish kills, might be kept within tolerable limits. I'ear-critical stream levels, which may eliminate trout from a stream reach, may also be improved by augmentation. Some trout streams may have their fishery length extended by improving temperatures where ground-water runoff is inadequate.

It may be possible to create permanent fisheries in streams that have only intermittent flows. In Door County, st"eams tributary to Lake Michigan have very low summer flows. Trout and salmon from the lake attempt to use these streams for spawning (R. W. Hunt and L. T. Kernen, oral communs., 1970), but the 
fry apparently do not survive the period of low streamflow. If adequate streamflow could be maintained by augmentation, the surviving fry might supplement and enhance the stocking program in Lake Michigan.

Augmentation need not be restricted to trout streams. It can be used to offset the effects of stream eutrophication and the "rmal and organic pollution and to improve other aspects related to stream degradation. Stream eutrophication refers to the gradual enrichment that may result in undesirable increases of plants and other aquatic organisms in the streams. Streamflow augmontation can improve the deteriorating temperature and DO levels that may be associated with the eutrophication process and can improve other quality characteristics of the stream. Temperature improvement achieved through augmentation also would reduce the stress imposed on the stream environment by thermal pollution. Temperature reduction would be pronounced because the temperature levels associated with thermal pollution are higher than those encountered in this study.

\section{ADDITIONAL STUDIES}

The present project revealed several subjects that would benefit from additional study. An economic study would be necersary to adequately describe the feasibility of augmentation. A more detailed analysis of the effectiveness of flow augmentation in streams having either critical DO levels or critical temperatures would be desirable. Detailed study of the response of trout populations and other stream biota to improved habitat conditions is also necessary to fully evaluate the effectiveness of augmentation.

Although economic consideration is necessary to determine the feasibility of streamflow augmentation, a general economic study may provide little useful information. Because each stream is unique, an economic study of each potential application may be the only meaningful approach.

In the present study an adequate (but conservative) estimate of the effect of augmentation on DO levels was provided by a simple mass-balance technique. Although this may be adecuate in most applications, a better understanding of the effect of augmentation on the factors that influence occurrence and distribution of dissolved oxygen is warranted. The interaction of such factors as increased volume, surface area, velocity and depth, temperature changes, and changes in biologic activity must be known to evaluate the effects of augmentation. A study to describe DO variations with time and distance under different conditions of flow, temperature, and initial values would als? be required. 
Temperature studies are needed where severe temperature problems occur downstream from surface impoundments. Many streams with such problems are known in Wisconsin-a few below lakes and several below small millponds. Plum Creek in Vilas County and the Tomorrow River in Portage County are examples suggested by personnel of the Department $\mathrm{cf}$ Natural Resources. Study of a trout stream affected by an impoundment or a lake would permit further evaluation of temperature improvement achieved through augmentation, combinec' with investigation of an alternate source of water.

Benthic organisms and aquatic vegetation are essential factors in the trout habitat, and a detailed study should be conducted to evaluate the biological response to augmentation. The study should provide detailed quantitative data on the stream biota throughout the year. Several years of pre-augmentation study would be required to separate natural changes from changes caused by augmentation. A concurrent study of a control stream or an isolated reach of the study stream could be substituted for the pre-augmentation study. In either approach a minimum of two seasons of augmentation would be needed to include a conıplete cycle of the stream biota.

The response of trout populations to improved hakitat conditions would provide the best evaluation of the effectiveness of flow augmentation in improving trout habitat. A detailed study of changes in age class and (or) changes in pounds of trout per unit area would provide better evaluation of response to augmentation. Other factors affecting the stream must be held essentially constant to assure that observed changes are responses to augmenation.

The recommended studies could be combined in some streams. The study below an impoundment could provide data on water temperature and DO. If the investigation continued for several years, a comprehensive study of how stream biota and trout populations respond to augmentation could be conducted.

\section{CONCLUSIONS}

Trout streams can be improved by augmenting strec.mflow with pumped ground water. In Black Earth Creek and the Little Plover River changes in temperature and DO were observed during augmentation. In both streams temperature extremes were moderated, and DO concentrations increased during the augmentation period. A model was used to predict potential temporature improvement during critical conditions. An estimate of rotential DO 
improvement during critical conditions can be provided by a simple mass-balance technique. Improvement in living space was infirectly indicated by increases in stream volume and stage.

Both maximum and minimum stream temperatures changed significantly near the augmentation sites, but the effects rapidly decreased downstream. In the Little Plover River maximur - temperatures were lowered as much as $5^{\circ} \mathrm{F}\left(3^{\circ} \mathrm{C}\right)$ at the augmertation site, but temperature change became insignificant more than 1 mile downstream. During critical conditions maximum temperatures may be lowered $10^{\circ} \mathrm{F}\left(6^{\circ} \mathrm{C}\right)$ or more, and under conditions of severely restricted ground-water runoff the temperature improvement may extend much farther downstream. Minimurn temperatures in Black Earth Creek increased somewhat in response to augmentation during the test period.

In both streams dissolved-oxygen levels increased during augmentation. Minimum DO levels increased slightly in the Little Plover River, where levels are typically more than $7 \mathrm{mg} / \mathrm{l}$ throughout the year. In Black Earth Creek, where DO levels have been critically low in the past, minimums were increased as much as 2 $\mathrm{mg} / \mathrm{l}$ or more below the augmentation site. Minimums ob erved in the problem reach were $7 \mathrm{mg} / \mathrm{l}$ or more throughout tre test period. A mass-balance analysis indicates that augmentation accounted for an increase of approximately $1 \mathrm{mg} / \mathrm{l}$, although this is probably a conservative estimate because it does not ccnsider changes in the reoxygenation characteristics of the stream during augmentation.

Increased flow volumes were retained through the study $\mathrm{r}$ ?aches of both streams. Increased volumes probably will be retained in any stream that typically receives ground-water runoff. All aspects of habitat improvement observed except temperature depend on retention of the augmenting flow. Temperature improvement, however, may be more pronounced in stream reaches where no ground-water runoff occurs.

In summary, streamflow augmentation from ground water should be considered in the light of resource management. Augmentation increases the amount of ground water enterirg the stream during the augmentation period and decreases the amount of ground-water runoff while storage is being replenished. Terms in the water budget, however, remain nearly balanced, and only timing in the stream-aquifer system is significantly af'ected. Hence, augmentation appears to provide a means to achieve greater benefit from an existing resource without upsetting the eristing balance. 


\section{SELECTED REFERENCES}

Anderson, E. R., 1954, Energy-budget studies, in Water loss investigations: Lake Hefner studies, technical report: U.S. Geol. Survey Prof. Paper 269, p. 71-119.

Benson, N. G., 1953, The importance of ground water to trout populations in the Pigeon River, Michigan, in N. Am. Wildlife Conf : 18th, Washington, D.C., 1953, Trans., p. 268-281.

Brasch, J. G., McFadden, J. T., and Kmiotek, Stanley, 1962, The eastern brook trout-its life history, ecology, and management: Wisconsin Conserv. Dept. Pub. 226, 11 p.

Brown, G. W., 1969, Predicting temperatures of small streams: Water Resources Research, v. 5 , no. 1 , p. 68-75.

Brynildson, O. M., 1967, Dispersal of stocked trout in five Wiscorsin streams: Wisconsin Conserv. Dept. Research Rept. 26, 8 p.

Brynildson, O. M., Hacker, V. A., and Klick, T. A., 1964, Brown trout-its life history, ecology, and management: Wisconsin Conserv. Dept. Pub. 234, $15 \mathrm{p}$.

Burdick, G. E., Lipschuetz, Morris, Dean, H. F., and Harris, E. F., 1954, Lethal oxygen concentrations for trout and smallmouth bass: New York Fish and Game Jour., v. 1, no. 1, p. 84-97.

Burt, W. V., 1958, Heat budget terms for middle Snake River reservoirs, in Water temperature studies of the Snake River: U.S. Fish and Wildlife Service Tech. Rept. 6, 23 p.

Churchill, M. A., 1965, Control of temperature through streamflow regulation, in Streamflow regulation for quality control: U.S. Public Health Service Pub. 999-W P-30, p. 179-192.

Cline, D. R., 1963, Hydrology of upper Black Earth Creek basir, Wisconsin: U.S. Geol. Survey Water-Supply Paper $1669-C, 27$ p.

1965, Geology and ground-water resources of Dane County, Wisconsin: U.S. Geol. Survey Water-Supply Paper 1779-U, 64 p.

Collier, C. R., 1963, Sediment characteristics of small streams in southern Wisconsin 1954-59: U.S. Geol. Survey Water-Supply Peper 1669-B, $34 \mathrm{p}$.

Dury, G. H., 1964, Subsurface exploration and chronology of underfit streams: U.S. Geol. Survey Prof. Paper 452-B, 56 p.

Edinger, J. E., Duttweiler, D. W., and Geyer, J. C., 1968, The response of water temperatures to meteorological conditions: Water Resources Research, v. 4, no. 5, p. 1137-1143.

Fair, G. M., and Geyer, J. C., 1965, Water supply and waste-water disposal: New York, John Wiley and Sons, $911 \mathrm{p}$.

Fry, F. E. J., 1959, The oxygen requirements of fish, in 2nd Seminar on Biological Problems in Water Pollution, Trans: U.S. Public Health Service Tech. Rept. W60-3, p. 106-109.

Holt, C. L. R., Jr, 1965, Geology and water resources of Portage County, Wisconsin: U.S. Geol. Survey Water-Supply Paper 1796, 77 p.

Jenkins, C. T., 1968, Techniques for computing rate and volume of stream depletion by wells: Ground Water, v. 6, no. 2, p. 37-46.

Jones, J. R. E., 1952, The reactions of fish to water of low diss?lved oxygen concentrations: Jour. Experimental Biology, v. 29, p. 402-415.

Langbein, W. B., and Durum, W. H., 1967, The aeration capacity of streams: U.S. Geol. Survey Circ. 542, 6 p. 
Latta, W. C., 1965, Relationship of young-of-the-year trout to mature trout and ground water: Am. Fisheries Soc. Trans., v. 94, no. 1, p. 32-39.

Marciano, J. J., and Harbeck, G. E., Jr., 1954, Mass-transfer studies, in Water loss investigations: Lake Hefner studies, technical report: U.S. Geol. Survey Prof. Paper 269, p. 46-70.

McKee, J. E., and Wolf, H. W., 1963, Water quality criteria: California Resources Agency, State Water Quality Control Board Pub. 3-A, 548 p.

O'Connor, D. J., 1967, The temporal and spacial distribution of dissolved oxygen in streams: Water Resources Research, v. 3, no. 1, p. 65-79.

Raphael, J. M., 1962, Prediction of temperatures in rivers and reser-roirs: Am. Soc. Civil Engineers Proc., Jour. Power Div., v 88, p. 157-181.

Schraufnagel, F. H., Montie, L. A., VanderVeldon, G. A., and Lueschow, L. A., 1964, Report on the investigation of Black Earth Creek and Cross Plains sewage treatment facilities made during 1963 and 1964: Wisconsin State Board of Health and Comm. on Water Pollution, mimeo. rept., 6p.

Shepard, M. P., 1955, Resistance and tolerance of young speckled trout (Salvelinus fontinalis) to oxygen lack, with special reference to low oxygen acclimation: Canada Fisheries Research Board Jour., v. 12, no. 3, p. 387-446.

Streeter, H. W., and Phelps, E. B., 1925, A study of the pollution and natural purification of the Ohio River: U.S. Public Health Service Bull. 146, $75 \mathrm{p}$.

U.S. Geological Survey, 1958, Compilation of records of surface waters of the United States through 1950, pt. 4, St. Lawrence River basin: U.S. Geol. Survey Water-Supply Paper 1307,389 p.

1962, Surface water records of Wisconsin, 1961: Madison, U.S. Geol. Survey ann. rept., $140 \mathrm{p}$.

1963, Surface water records of Wisconsin, 1962: Madison, U.S. Geol. Survey ann. rept., $136 \mathrm{p}$.

1964a, Compilation of records of surface waters of the United States, October 1950 to September 1960, pt. 4, St. Lawrence River basin: U.S. Geol. Survey Water-Supply Paper 1727, 371 p.

1964b, Surface water records of Wisconsin, 1963: Madison, U.S. Geol. Survey ann. rept., $150 \mathrm{p}$.

1965, Surface water records of Wisconsin, 1964: Madison, U.S. Geol. Survey ann. rept., $193 \mathrm{p}$.

1966, Water resources data for Wisconsin, 1965, pt. 1 and 2: Madison, U.S. Geol. Survey ann. rept., 212 p.

1967, Water resources data for Wisconsin, 1966, pt. 1 and 2: Madison, U.S. Geol. Survey ann. rept., 215 p.

1968, Water resources data for Wisconsin, 1967, pt. 1 and 2: Madison, U.S. Geol. Survey ann. rept., 215 p.

Velz, C. J., and Gannon, J. J., 1960, Forecasting heat loss in ponds and streams: Water Pollution Control Federation Jour., v. 32, p. 392-417.

Weeks, E. P., Ericson, D. W., and Holt, C. L. R., Jr., 1965, Hydrology of the Little Plover River basin, Portage County, Wisconsin, and the effects of water resource development: U.S. Geol. Survey Water-Supply Paper 1811, $78 \mathrm{p}$.

Weeks, E. P., and Stangland, H. G., 1971, Effects of irrigation on streamflow in the central sand plain of Wisconsin: U.S. Geol. Survey open-file report, 224 p., 19 figs. 
Whitmore, C. M., Warren, C. E., and Doudorff, Peter, 1960, Avoidance reactions of Salmonid and Centrarchid fishes to low oxygen concentrations: Am. Fisheries Soc. Trans., v. 89, no. 1, p. 17-26.

White, R. J., and Brynildson, O. M., 1967, Guidelines for management of trout stream habitat in Wisconsin: Wisconsin Dept. Nat. Resources Tech. Bull. $39,65 \mathrm{p}$.

Wiebe, A. H., and McGavok, A. M., 1932, The ability of several species of fish to survive on prolonged exposure to abnormally high concentrations of dissolved oxygen: Am. Fisheries Soc., 62nd Ann. Mtg., Baltimore, 1932, Trans., p. 267-274.

Wisconsin Conservation Department, 1966, Wisconsin trout streams: Wis. Conserv. Dept. Pub. 213-66, 75 p.

Zeller, Robert, 1967, Summary of current theories and studios relating to temperature prediction, in Water temperature influences, effects, and control: Federal Water Pollution Control Admin., Pacific Northwest Symposium on Water Pollution Research, 12th, Portland, Oreg., 1967, p. 111-156. 


\section{A P P E N D I X}




\section{APPENDIX-DEVELOPMENT OF A MODEL FOR PREDICTING MAXIMUM OR MINIMUN" STREAM TEMPERATURES}

A major objective of this study was to determine tre change in stream temperature caused by augmentation of streamflow with ground water. During augmentation, however, no physical means was available to measure the difference between the observed stream temperature and that which would have occurred without augmentation. Hence, a mathematical model to predict stream temperatures relative to observed air temperatures, both during normal conditions and during augmentation, was developed. With this model it also was possible to estimate the effectiveness of flow augmentation for conditions more extreme than those that occurred during the test period. The model proved satisfactory in the Little Plover River and Black Earth Creek.

When water of a particular temperature is placed in an environment that has a different temperature, the water temperature will attempt to achieve equilibrium with the environment. In both the Little Plover River and Black Earth Creek, maximum and minimum stream temperatures occur concurrently with maximum or minimum air temperatures. Although water temperatures seldom reach air temperatures, the difference between them decreases downstream.

If a specific temperature, such as the daily maximum, were observed throughout a stream reach, the profile of maximum stream temperatures downstream would look like that presented in figure 24. The change in water temperature may be described mathematically by:

$$
\frac{d T D}{d L}=-k\left(T_{\Delta}-T\right),
$$

where $\left(T_{\Delta}-T\right)$ is the remaining difference between air temperature and water temperature at any point downstream, $\frac{d T D}{d L}$ is the rate at which the temperature difference is decreasing, and $k$ is a coefficient reflecting the response of the water to heat gained or lost from solar radiation or conduction between the water and the environment. Stream depth and velocity are assumed constant, and lateral and longitudinal mixing are assumed complete and immediate. Integrating equation 1 yields :

$$
\log _{\theta}\left(T_{\Delta}-T\right)=-k L+C \text {. }
$$

The initial temperature difference at $L=0$ is $\left(T_{\Delta}-T_{\sqrt{ }}\right)$. Using this boundary condition to solve for $C$ yields:

$$
T_{\Delta}-T=\left(T_{\Delta}-T_{i}\right) e^{-k L},
$$

which describes the curve shown in figure 24 . 


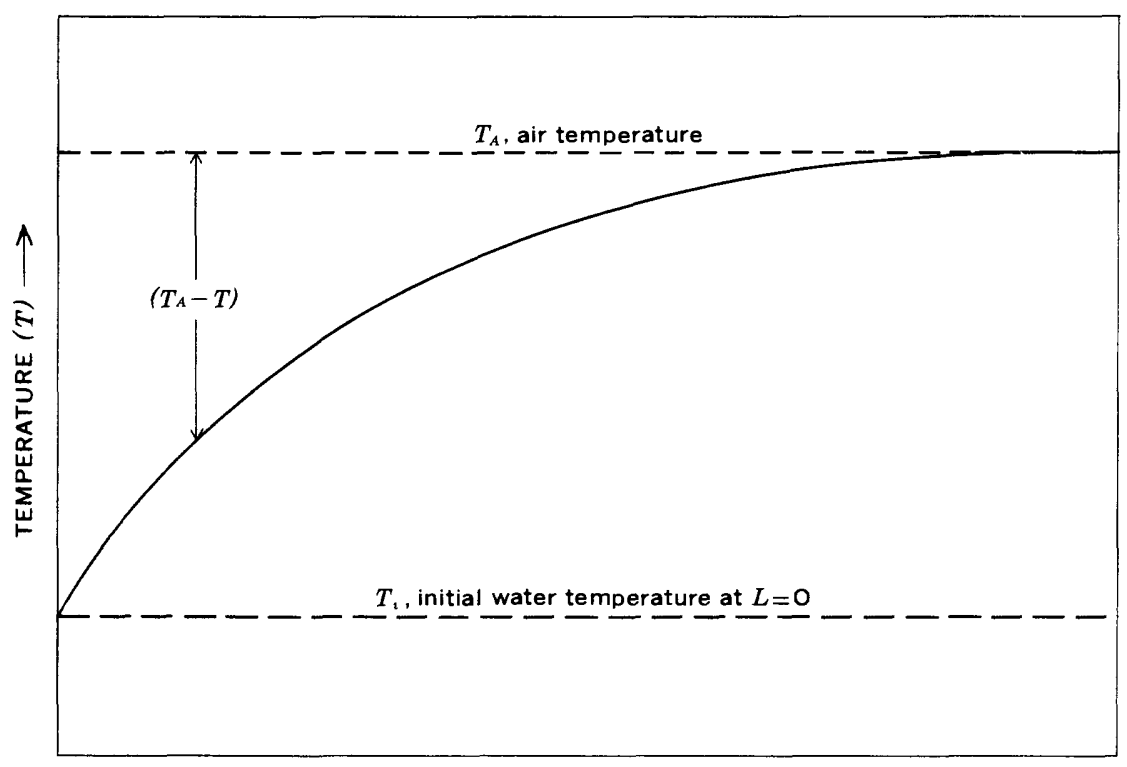

STREAM DISTANCE $(L) \longrightarrow$

FIGURE 24.-Theoretical water-temperature profile resulting if temperature at $L=0$ is held constant.

However, observed profiles in the Little Plover River and Black Earth Creek are not adequately described by the theoretical profiles (fig. 25). Ground-water runoff entering a stream at c. constant temperature causes a departure from the theoretical profile, as shown. Ground-water runoff is not constant throughout the stream reach because of stream morphology, streambed permeability, and areal differences in water-table gradients, and it is difficult to study the effect on stream temperatures by analytical methods. Hence, an approximation is used to superimpose the influence of ground-water runoff on the theoretical temperature profile.

Ground-water runoff is defined for small increments of distance, $\Delta \mathrm{L}$, and for each increment two steps are employed to yield an approximate solution for the temperature difference remaining. To facilitate computation, $\left(T_{\mathbf{A}}-T\right)$ in equation 3 is replaced by $T_{\mathrm{B}}$, and $\left(T_{\mathbf{A}}-T_{\mathrm{v}}\right)$ is replaced by $T_{\mathrm{i}}$ so that, rewriting:

$$
T_{\mathrm{B}}=T_{\mathrm{i}} e^{-k L} \text {. }
$$

The first step is to solve equation 4 for $T_{s}$. Next, a standard mixing equation is employed to superimpose the effect of groundwater runoff on the initial solution. The mixing equation, expressed in terms appropriate to the present analysis is :

$$
T_{\Sigma}=\frac{Q_{\mathrm{B}}\left(T_{\mathrm{B}}\right)+Q_{\mathrm{OW}}\left(T_{\mathrm{GW}}\right)}{Q_{\mathrm{B}}+Q_{\mathrm{GW}}},
$$


where: $\quad T_{L}=$ Remaining difference between air temperature and water temperature after mixing with ground water;

$T_{s}=$ Theoretical stream temperature difference from solution of equation 4 ;

$T_{a W}=$ Difference between air temperature and groundwater temperature;

$Q_{s}=$ Streamflow volume, in cfs, at upper end of stream increment $\Delta L$;

and $Q_{a W}=$ Ground-water runoff, in cfs, occurring within stream increment $\Delta L$.

This procedure is then repeated for each increment $\Delta L$ in which ground-water runoff occurs (fig. 26). For each subsequent step $T$, is equal to $T_{L}$ from the preceding step. Hence, $L$ is no longer the total distance downstream but is replaced by $\Delta L$, representing the incremental stream length for which ground-water runoff is defined. The best approximation is obtained when $\Delta L$ is chosen as small as is practical.

The response coefficient, $k$, was assumed to be proportional to

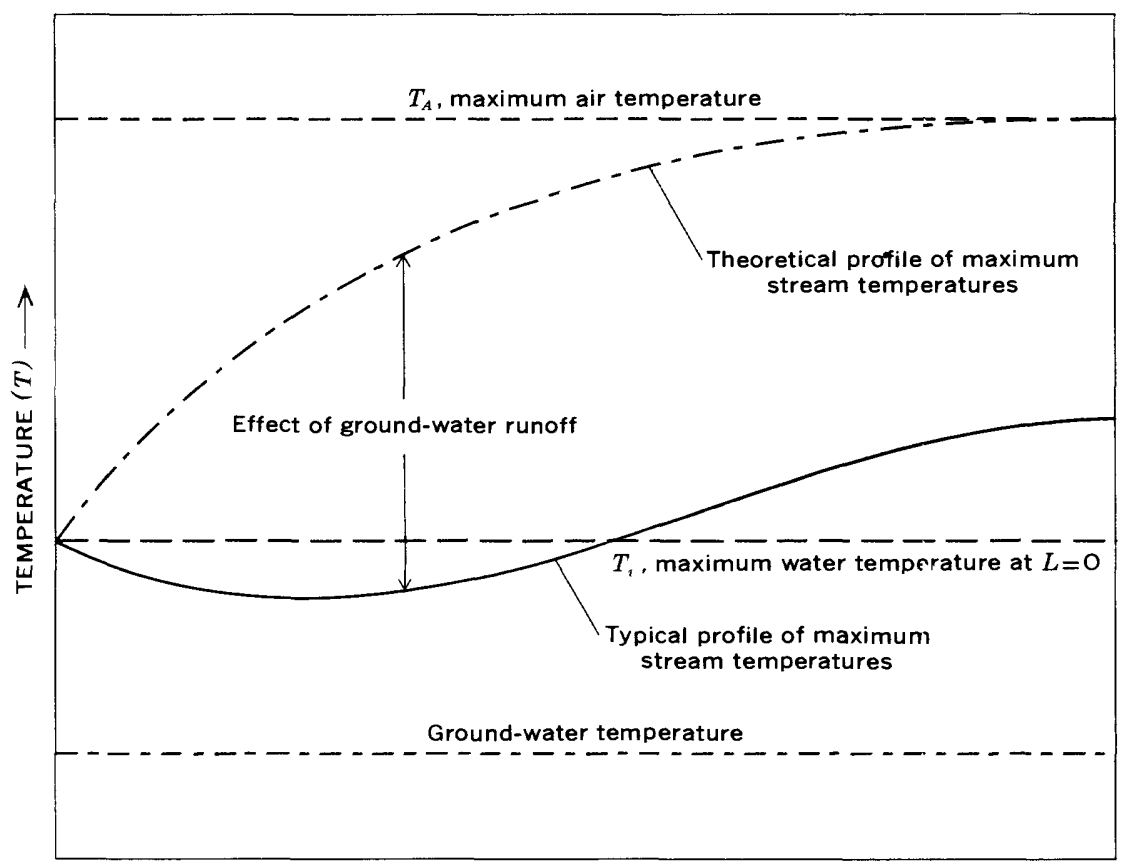

STREAM DISTANCE $(L) \longrightarrow$

Figure 25.-Typical profile of maximum water temperatures showing the effect of ground-water runoff compared to the theoretical profile. 


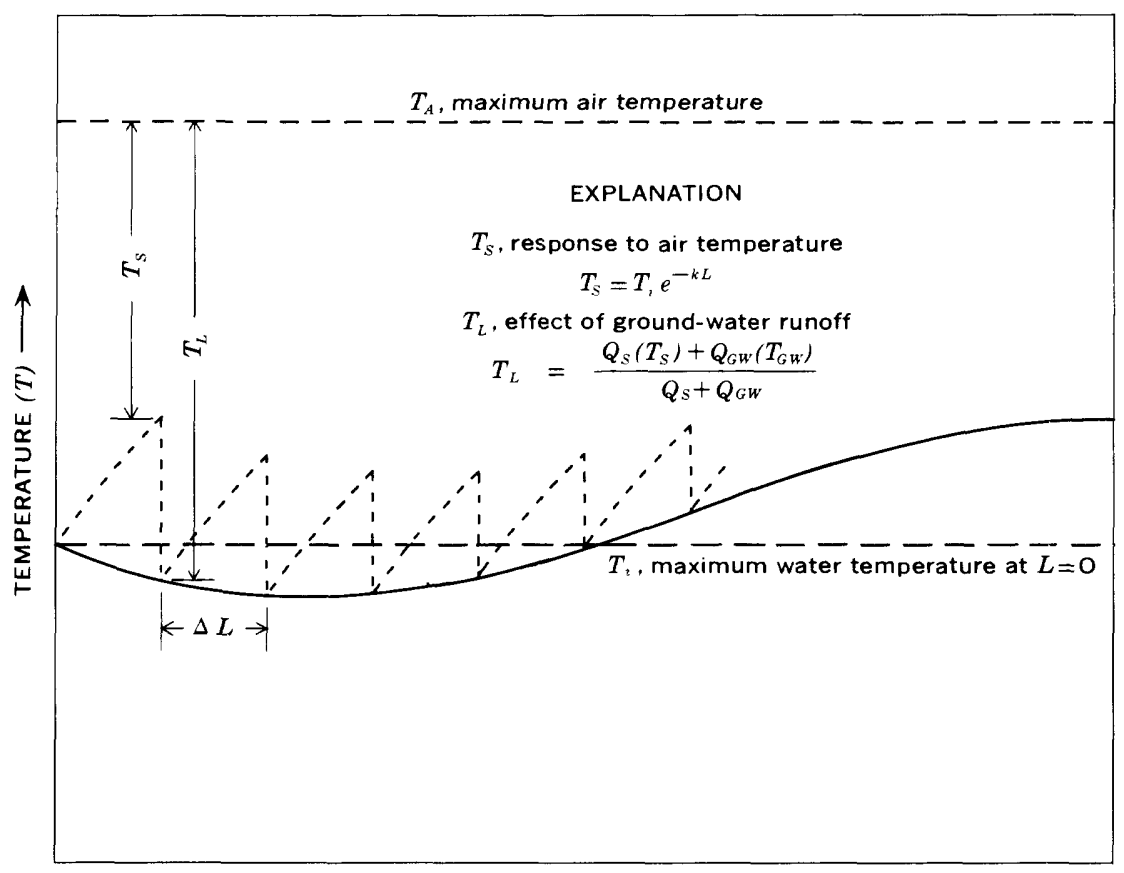

STREAM DISTANCE $(L) \longrightarrow$

FigURE 26.-Profile of maximum water temperatures abtained by scperimposing the effect of ground-water runoff on the theoretical profile.

the initial temperature difference $\left(T_{\Delta}-T\right)$ (D. W. Duttweiler, written commun., 1961). For both the Little Plover River and Black Earth Creek, $k$ was determined empirically. First, groundwater runoff was defined for length increments, $\Delta L=0.1$ mile, ly a combination of seepage measurements and analysis of the observed temperature profile during base-flow conditions. Assuming ground-water runoff remained relatively constant, successive approximations were used to obtain a $k$ which provided the best approximation to an observed profile of maximum stream temperatures for 1 day. In the Little Plover River, $k$ was determined on the basis of observed data for September 21, 1968, yielding a value $k=0.01\left|T_{4}-T_{i}\right|$, or $k=0.01\left|T_{i}\right|$. The recorders, provided by the Department of Natural Resources, recorded temperature in degrees Fahrenheit. For convenience, the coefficient $k$ was determined on the basis of Fahrenheit degrees, and all subsequent calculations in this appendix are based on degrees Fahrenheit.

Table 2 presents the computations required to define the profile of maximum stream temperatures in the Little Plover River for September 14, a typical day within the augmentation period. The 
actual temperatures recorded at site $4 \quad(L=0.84)$ and site 2 ( $L=1.59$ ) are also included to show the accuracy of the predicted values.

The profile of minimum stream temperatures is obtained by the same procedure. However, it should be noted that tre quantities $T$, and $T_{G W}$ may be negative.

TABLE 2.-Computations to define profile of maximum water temperatures in the Little Plover River for September 14, 1968

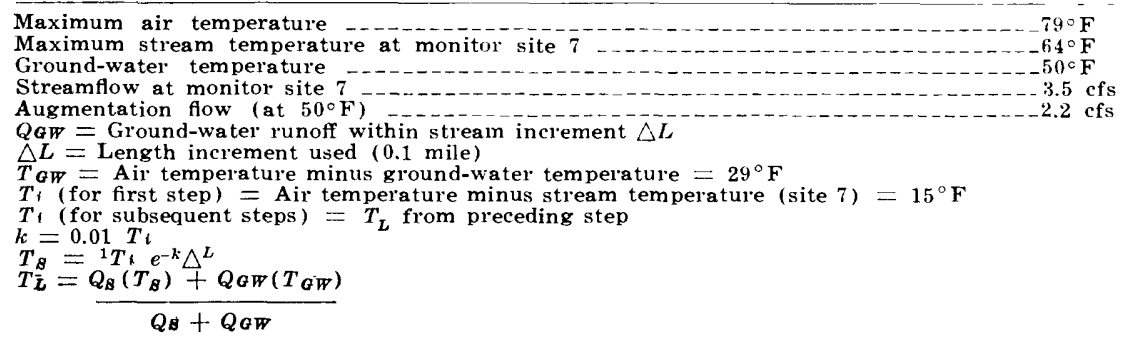

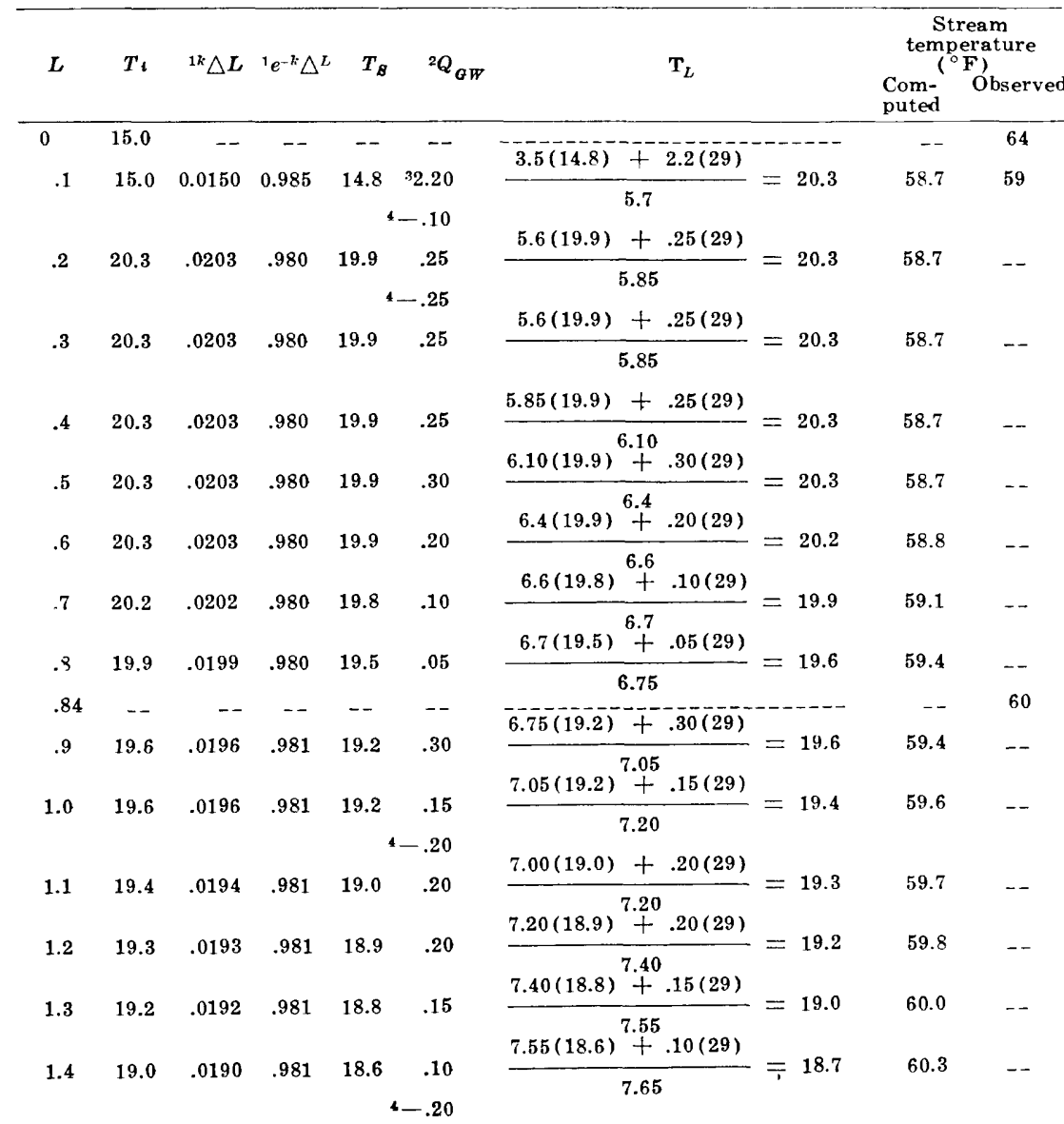


TABLE 2.-Computations to define profile of maximum water temperatures in the Little Plover River for September 14, 1968-Continued

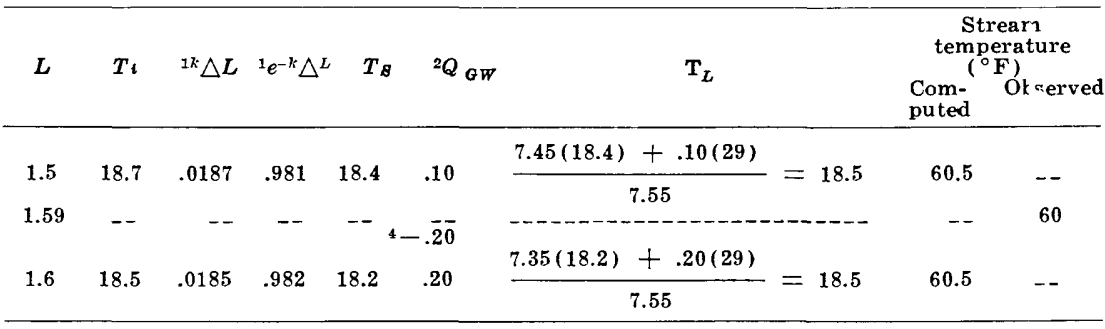

1 Because of ground-water inflow, computations are repeated using $L=\Delta L$ for each step and $T_{t}=T_{L}$ from the previous step.

${ }_{2}$ Ground-water inflow, inferred from temperature-profile analysis, figures 3 and 4 , in text.

3 Augmentation flow.

4 Negative values are water losses that do not change temperature, but decrease $Q$ downstream. The reduced $Q$ is used in the calculations of $T_{L}$ for the next stream increment.

TABLE 3.-Comparison of computed and observed stream temperatures in the Little Plover River

\begin{tabular}{|c|c|c|c|c|c|c|c|}
\hline \multirow{2}{*}{$\begin{array}{c}\text { Date } \\
(1968)\end{array}$} & \multirow{2}{*}{$\begin{array}{c}\text { Air } \\
\text { tempera- } \\
\text { ture }\end{array}$} & \multirow{2}{*}{$\begin{array}{c}\text { Stream } \\
\text { tempera- } \\
\text { ture at } \\
\text { site } 7 \\
\end{array}$} & \multirow{2}{*}{$\begin{array}{c}\text { Natural } \\
\text { streamflow } \\
\left(Q_{B}\right) \text { at } \\
\text { site } 7\end{array}$} & \multicolumn{2}{|c|}{$\begin{array}{l}\text { Stream temperature } \\
\text { at site } 4\left(0^{\circ} \mathrm{F}\right)\end{array}$} & \multicolumn{2}{|c|}{$\begin{array}{l}\text { Stream temperature } \\
\text { at site } 2\left({ }^{\circ} \mathrm{F}\right)\end{array}$} \\
\hline & & & & Computed & Observed & Computed & Observed \\
\hline \multicolumn{8}{|c|}{ Streamflow and maximum temperatures } \\
\hline Sept. $14^{1}$ & 79 & 64 & 3.5 & 59.4 & 60 & 60.5 & 60 \\
\hline Sept. $16^{1}$ & 74 & 61 & 3.1 & 56.4 & 58 & 57.6 & 58 \\
\hline Sept. 21 & 76 & 63 & 3.0 & 59.7 & 60 & 59.3 & 59 \\
\hline Sept. 22 & 77 & 63 & 2.9 & 59.8 & 60 & 59.7 & 59 \\
\hline Sept. 23 & 78 & 61 & 3.0 & 58.9 & 58 & 58.2 & 57 \\
\hline Sept. 24 & 70 & 62 & 3.1 & 58.4 & 59 & 57.8 & 58 \\
\hline Sept. 25 & 56 & 55 & 2.8 & 53.0 & 53 & 52.3 & 52 \\
\hline \multicolumn{8}{|c|}{ Streamflow and minimum temperatures } \\
\hline Sept. $14^{1}$ & 44 & 51 & 3.5 & 50.2 & 50 & 50.0 & 50 \\
\hline Sept. $16^{1}$ & 52 & 53 & 3.1 & 51.3 & 52 & 51.1 & 53 \\
\hline Sept. 21 & 41 & 50 & 3.0 & 49.2 & 48 & 48.6 & 49 \\
\hline Sept. 22 & 57 & 54 & 2.9 & 53.2 & 53 & 53.1 & 53 \\
\hline Sept. 23 & 60 & 56 & 3.0 & 55.2 & 54 & 55.4 & 53 \\
\hline Sept. 24 & 48 & 52 & 3.1 & 50.6 & 50 & 50.1 & 51 \\
\hline Sept. 25 & 48 & 49 & 2.8 & 49.3 & 48 & 49.3 & 48 \\
\hline
\end{tabular}

${ }^{1}$ Stream temperatures on these days are affected by augmentation.

The reliability of estimates provided by the model may be irferred from table 3, where computed temperatures during both augmentation and normal flow conditions are compared to observed temperatures for 10 days. In all cases predicted temperatires were within $2^{\circ} \mathrm{F}$ of the observed temperatures, which is nearly the limit of accuracy of the temperature recorders used $\left( \pm 1^{\circ} \mathrm{F}\right)$.

The temperature model was also used to predict temperatires in Black Earth Creek. The value of $k$ for Black Earth Creek was $k=0.02\left|T_{\imath}\right|$. Stream temperatures as much as 4.75 miles below the augmentation site were predicted within approximately $2^{\circ} \mathrm{F}$ 
of observed values. Hence, the model was used with confidence to predict the effect of augmentation under various combinations of maximum and minimum air temperatures, initial water temperatures, and augmentation schemes for the Little Plover River and Black Earth Creek as presented in the text. 